NBER WORKING PAPER SERIES

\title{
DOES THE SECTOR BIAS OF \\ SKILL-BIASED TECHNICAL CHANGE \\ EXPLAIN CHANGING WAGE \\ INEQUALITY?
}

Jonathan E. Haskel

Matthew J. Slaughter

Working Paper 6565

http://www.nber.org/papers/w6565

\section{NATIONAL BUREAU OF ECONOMIC RESEARCH \\ 1050 Massachusetts Avenue \\ Cambridge, MA 02138 \\ May 1998}

For helpful comments we thank George Borjas, Larry Katz, Steve Machin, Alan Manning, Adrian Wood, and seminar participants at Dartmouth College, Harvard University, the London School of Economics, University of Essex, and University of Nottingham. For generous assistance with data we thank David Autor, Eli Berman, Larry Katz, Larry Mishel, and David Webster. For financial support Haskel thanks the U.K. Economic and Social Research Council for grant \#R000236653 and Slaughter thanks the Russell Sage Foundation for grants \#85-96-18 and \#85-97-18. Finally, for outstanding research assistance we thank Yiva Heden. Any opinions expressed are those of the authors and not those of the National Bureau of Economic Research.

(C) 1998 by Jonathan E. Haskel and Matthew J. Slaughter. All rights reserved. Short sections of text, not to exceed two paragraphs, may be quoted without explicit permission provided that full credit, including (C) notice, is given to the source. 
Does the Sector Bias of Skill-Biased Technical

Change Explain Changing Wage Inequality?

Jonathan E. Haskel and Matthew J. Slaughter

NBER Working Paper No. 6565

May 1998

JEL Nos. F1, J3, O3

ABSTRACT

This paper examines whether the sector bias of skill-biased technical change (sbtc) explains changing skill premia within countries in recent decades. First, using a two-factor, two-sector, twocountry model we demonstrate that in many cases it is the sector bias of sbtc that determines sbtc's effect on relative factor prices, not its factor bias. Thus, rising (falling) skill premia are caused by more extensive sbtc in skill-intensive (unskill-intensive) sectors. Second, we test the sector-bias hypothesis using industry data for many countries in recent decades. An initial consistency check strongly supports the hypothesis. Among ten countries we find a strong correlation between changes in skill premia and the sector bias of sbtc during the 1970s and 1980s. The hypothesis is also strongly supported by more structural estimation on U.S. and U.K. data of the economy-wide wage changes "mandated" to maintain zero profits in all sectors in response to the sector bias of sbtc. The suggestive mandated-wage estimates match the direction of actual wage changes in both countries during both the 1970 s and the 1980 s. Thus, the empirical evidence strongly suggests that the sector bias of sbtc can help explain changing skill premia.

Jonathan E. Haskel

Department of Economics

Queen Mary and Westfield College

University of London

London E1 4NS

ENGLAND

j.e.haskel@qmw.ac.uk
Matthew J. Slaughter

Department of Economics

Dartmouth College

309 Rockefeller Hall

Hanover, NH 03755

and NBER

slaughter@dartmouth.edu 


\section{Introduction}

Many economists have argued that skill-biased technological change (sbtc) has contributed to rising wage inequality in many countries by shifting relative labor demand towards skilled labor. The bulk of empirical evidence supporting this "sbtc hypothesis" seems to be the occurrence of sbtc in many sectors, i.e., its pervasiveness. Many papers (including Bound and Johnson (1992) and Berman, Bound, and Griliches (1994) for the United States and Berman, Bound, and Machin (1997) for several developed countries) document rising relative employment of skilled workers within sectors despite their rising relative wages. Complementing this, Berman, Bound, and Griliches (1994), Krueger (1993), and Autor, Katz, and Krueger (1997) document the correlation between skill upgrading and measures such as computerization and research and development.

There are at least two unresolved issues with the sbtc hypothesis. First, some economists argue that this hypothesis is incomplete because the data do not reveal a clear acceleration in the pace of sbtc. Because many measures of U.S. inequality did not increase until about 1980 even though sbtc has been occurring for decades, Mishel and Bernstein (1996), Howell (1995), and Wood (1998) argue a 1980s acceleration is necessary to explain rising inequality. Evidence for this acceleration is somewhat mixed, however. With aggregate data on U.S. relative wages and relative labor supplies, Johnson's (1997) calculations indicate this acceleration might have occurred. Similarly, Autor, Katz, and Krueger (1997) report evidence of acceleration for the 1970s and 1980s relative to the 1960s. In contrast, Mishel and Bernstein (1996) fail to find greater acceleration in the 1980s and 1990s relative to 1973-1979.

A second problem with the sbtc hypothesis is there exists sharp disagreement about the theoretical effect of sbtc--or more generally all kinds of technical change (tc)--on relative factor prices. The literature disagrees about whether changes in relative factor prices depend on the factor bias of tc (i.e., whether tc favors a certain factor of production) or the sectorbias of tc (i.e., whether tc occurs in certain sectors). In one-sector models the question of sector bias does not arise. But in multi-sector models sector bias is critical. Adding a second sector can 
completely reverse the one-sector effects of tc because tc changes the relative profitability of sectors. This alters intersectoral factor demands and thereby changes relative factor prices. Even in multi-sector models, there is also theoretical disagreement on the effect of tc on relative wages when tc affects product prices. Many authors have addressed some of these issues and seem to contradict each other in important ways: e.g., Baldwin and Cain (1997), Berman, et al (1997), Bhagwati and Dehejia (1994), Davis (1997), Krugman (1995), Leamer (1996), Richardson (1995), and Wood (1995). ${ }^{1}$

Thus, there are two important unresolved issues with the sbtc hypothesis, one arising from data and the other from theory. Moreover, there is a noticeable disjoint between these two issues. Empirical work, mostly by labor economists, typically addresses pervasiveness versus acceleration. Theoretical work, mostly by trade economists, typically concerns factor bias versus sector bias. The object of this paper is to reconcile these two issues. We aim to do this by first presenting a theoretical framework that clarifies both these issues. Second, we apply this framework to cross-country data. We proceed as follows.

We begin by analyzing relative labor demand and wages in a simple general-equilibrium model of technical change and trade. Much of the theoretical work to date relies on diagrams and/or special assumptions (such as Leontief production technology). Our formal model has the advantage of greater generality and relates an open-economy multi-sector model familiar to trade economists to the partial-equilibrium one-sector model familiar to labor economists. With this model we try to reconcile various findings in the current theoretical literature.

Our key theoretical result we label the "sector-bias hypothesis." In many cases it is the sector bias of technical change, rather than the factor bias, that determines tc's effect on relative factor prices. That is, in many cases rising (falling) skill premia are caused by tc that is concentrated in the skilled-labor-intensive (unskilled-labor-intensive) sectors. We demonstrate

\footnotetext{
${ }^{1}$ For example, Richardson (1995, p. 41) comments that his analysis "undermines research that sweepingly but limply invokes 'technology' (technological karma) for trends in wage inequality. Only some kinds matter. Variable-rate sectoral growth in total factor productivity matters; factor-augmenting technological change does not (for example, computers that make skilled workers even more skilled)." In contrast, Krugman (1995, p. 18) concludes that "Those trade economists who have asserted that factor price trends depend only on the sector of technical change, and not at all on the factor bias of that change, have therefore got it almost exactly the wrong way around."
} 
that sector bias often matters even with endogenous product prices. This result has two important implications. First, the intuition of the one-sector model--i.e., that the factor bias of technological change is all that matters--is likely to be incorrect in a multi-sector setting. Second, rising wage inequality cannot be explained by either pervasive or accelerating tc alone. To change relative wages there must also be a sector bias as well. We do, however, establish an important caveat to this result. In the case of pervasive sbtc--the case extensively documented in the empirical labor literature--knowing the sector bias is not necessarily sufficient to determine the net effect on relative wages. For this case additional information on the nature of technical change is required.

Despite the extensive empirical work documenting sbtc, to the best of our knowledge there is no evidence on its sector bias. Therefore, we examine the sector bias of sbtc using industry data for ten developed countries during the 1970s and 1980s. Our evidence shows a strong correlation between the sector bias of sbtc and changing skill premia. In countries when wage inequality was falling, we find that sbtc was generally concentrated in unskilled-labor-intensive sectors. In contrast, when inequality was rising, sbtc was generally concentrated in skilledlabor-intensive sectors. Conditional on the caveat mentioned in the previous paragraph, this evidence is consistent with our sector-bias hypothesis. This evidence also offers an alternative explanation for cross-country differences in wage inequality to that relying on labor-market institutions. Blau and Khan (1996) and Fortin and Lemieux (1997) argue that countries experience similar demand shocks that translate into different inequality outcomes due to different labor-market institutions. Our results suggest that different demand shocks from different sector biases of sbtc also matter.

We establish these findings in two ways. First, in all ten countries we find a significant correlation between falling wage inequality and the concentration of sbtc in unskill-intensive sectors and similarly between rising inequality and concentration in skill-intensive sectors. These relationships are robust to sbtc measures derived from different production technologies and based on measures of computerization that are regarded as plausible correlates of sbtc. 
Our second approach builds on the methodology in Leamer (1996), Baldwin and Cain (1997), and Feenstra and Hanson (1997). Like them, we estimate the "mandated" economywide wage changes consistent with zero profits in all sectors. Our innovation is to estimate these changes in response to the sector bias of sbtc rather than in response to the sector bias of product-price changes or various measures of total-factor productivity growth. For the United States and the United Kingdom (countries for whom we have adequate data), we find that mandated wage changes match closely the observed changes for both countries during the 1970s and 1980s. Thus the sector bias of sbtc can account for much of the actual changes in U.K. and U.S. wage inequality over this period.

There are five additional sections to this paper. In section 2 we analyze sbtc in a generalequilibrium model. Section 3 outlines our empirical plan and explains our empirical measures of sbtc. Section 4 presents the initial empirical results and Section 5 the mandated-wage results. Section 6 concludes.

\section{Theoretical Framework: Technological Change and Relative Wages}

\section{$2 a$ Model Set-Up}

To understand how technological change affects relative wages we analyze a two-factor, two-sector, two-country model. The two factors are skilled and unskilled labor (S and U, respectively); the two products are machinery and apparel ( $\mathrm{M}$ and $\mathrm{A}$, respectively); and the two countries are home and foreign. Production technology is constant-elasticity-of-substitution (CES). This generalizes Leontief technology commonly used in the literature and, in contrast to Cobb-Douglas technology, distinguishes Hicks-neutral and factor-biased technological change. Machinery output $\left(\mathrm{Y}_{\mathrm{m}}\right)$ is given by equation (1)

$$
\boldsymbol{Y}_{m}=\boldsymbol{A}_{m}\left[\left(\theta_{m}{ }^{u} U_{m}\right)^{\rho}+\left(\theta_{m}{ }^{s} S_{m}\right)^{\rho}\right]^{/ \rho}
$$

and apparel output is written analogously in equation (2).

$$
Y_{a}=A_{a}\left[\left(\theta_{a}{ }^{u} U_{a}\right)^{\rho}+\left(\theta_{a}{ }^{s} S_{a}\right)^{\rho}\right]^{/ \rho}
$$


In both equations Y represents output and subscripts denote sector. The parameter $\sigma=1 /(1-\rho)$ is the elasticity of substitution between $\mathrm{S}$ and $\mathrm{U}$ within each industry. For simplicity we assume that both sectors have the same $\sigma$; for now we also assume that $\sigma$ is greater than one. ${ }^{2}$ Also, we assume sector M (A) employs factor S (U) relatively intensively.

To focus on production we assume identical homothetic consumer tastes worldwide. We also assume perfect interindustry factor mobility within each country. ${ }^{3}$ This implies that each country has one equilibrium national wage for $\mathrm{S}$ and $\mathrm{U}, \mathrm{w}_{\mathrm{S}}$ and $\mathrm{w}_{\mathrm{u}}$, respectively. In both countries each sector chooses its employment of $\mathrm{U}$ and $\mathrm{S}$ to maximize profits given exogenous product prices, factor prices, and production technology. First-order conditions of profit maximization imply that optimal relative labor demand is as follows.

$$
\left(\frac{S}{U}\right)_{\mathrm{k}}=\left(\frac{\theta_{k}^{s}}{\theta_{k}{ }^{u}}\right)^{\sigma-1}\left(\frac{w_{s}}{w_{u}}\right)^{-\sigma} \quad k=a, m
$$

Relative labor demand in each sector depends on relative wages, $\sigma$, and the factor-bias technology parameters. ${ }^{4}$

It will be important in what follows to define the factor bias and skill bias of any technical change. We define technical change in a sector $\mathrm{k}$ to be skill-biased (unskill-biased) if it raises (lowers) $(\mathrm{S} / \mathrm{U})_{\mathrm{k}}$ at given $\left(\mathrm{w}_{\mathrm{s}} / \mathrm{w}_{\mathrm{u}}\right)$. Technical change is defined as factor-neutral (or Hicksneutral) if it does not change $(\mathrm{S} / \mathrm{U})_{\mathrm{k}}$. It is clear from equation (3) that biased technical change can arise in a number of different ways. For example, sbtc can arise five ways: an increase in $\theta_{\mathrm{k}}{ }^{\mathrm{s}}$, ceterisparibus; an increase in ${\theta_{\mathrm{k}}}^{\mathrm{s}}$ that is larger than some increase in $\theta_{\mathrm{k}}{ }^{\mathrm{u}}$; an increase in $\theta_{\mathrm{k}}{ }^{\mathrm{s}}$ and a fall in $\theta_{\mathrm{k}}{ }^{\mathrm{u}}$; a fall in ${\theta_{\mathrm{k}}}^{\mathrm{s}}$ that is smaller than the fall in $\theta_{\mathrm{k}}{ }^{\mathrm{u}}$; and a fall in $\theta_{\mathrm{k}}{ }^{\mathrm{u}}$, ceteris

\footnotetext{
${ }^{2}$ There is a wide range of estimates of $\sigma$ : see Hamermesh (1993). Our assumption that $\sigma>1$ is well within that range. It is important to note that none of our empirical work hinges on the value of $\sigma$. In our theory discussion we assume that $\sigma>1$ for convenience; where relevant we note differences for $\sigma<1$--particularly for the Leontief case where $\sigma=0$.

3 This assumption, very common in trade theory, is made for convenience. We could limit factor mobility with unions, for example, but to focus on technology and be comparable with the literature we assume perfect mobility.

${ }^{4}$ In terms of (3) our sectoral factor-intensity assumption is $\left(\theta_{\mathrm{m}}{ }^{\mathrm{s}} / \theta_{\mathrm{m}}{ }^{\mathrm{u}}\right)>\left(\theta_{\mathrm{a}}{ }^{\mathrm{s}} / \theta_{\mathrm{a}}{ }^{\mathrm{u}}\right)$.
} 
paribus. ${ }^{5}$ These different cases matter for our analysis because in the data factor-biased tc is measured in terms of changes in $(\mathrm{S} / \mathrm{U})_{\mathrm{k}}$ at given $\left(\mathrm{w}_{\mathrm{s}} / \mathrm{w}_{\mathrm{u}}\right)$. This means that empirical measures of factor-biased tc cannot identify the exact changes in $\theta_{\mathrm{k}}{ }^{\mathrm{s}}$ and $\theta_{\mathrm{k}}{ }^{\mathrm{u}}$. It will therefore be important to consider ceteris paribus changes in one parameter and also relative changes in $\left(\theta_{\mathrm{k}}{ }^{\mathrm{s}} / \theta_{\mathrm{k}}{ }^{\mathrm{u}}\right)$. For simplicity we will usually exclude cases of technical regress.

Turning to sector bias, we distinguish isolated from pervasive technical change: tc is isolated when it occurs in one sector only and pervasive when it occurs in multiple sectors. Isolated tc has an obvious sector bias; namely, towards the sector enjoying the change. For pervasive tc that is also factor biased, define sector-neutral pervasive tc when both sectors experience the same change in $(\mathrm{S} / \mathrm{U})_{\mathrm{k}}$. Finally, pervasive sbtc (ubtc) is sector-biased towards sector $\mathrm{k}$ when $\mathrm{k}$ experiences a larger increase (decline) in $(\mathrm{S} / \mathrm{U})_{\mathrm{k}}$ than does the other sector.

The distinction between isolated and pervasive sbtc will be very important. A number of empirical studies have documented sbtc's pervasiveness. Yet almost all theoretical work in this literature has considered sector bias for the case of isolated sbtc only. We regard our analysis of the sector bias of pervasive sbtc to be an important contribution to the literature.

\section{$2 b$ Technological Change in a One-Sector Economy}

A one-sector model can be closed by combining equation (3) for just one sector with some upward-sloping relative-labor-supply curve. In this framework sbtc raises $\left(\mathrm{w}_{\mathrm{s}} / \mathrm{w}_{\mathrm{u}}\right)$ while ubtc lowers it. Factor-neutral tc doesn't alter $\left(\mathrm{w}_{\mathrm{s}} / \mathrm{w}_{\mathrm{u}}\right)$ because it doesn't alter $(\mathrm{S} / \mathrm{U})_{\mathrm{k}}$. Thus, in $a$ one-sector economy it is the factor bias of technological change that matters for relative factor prices.

\footnotetext{
5 A similar logic holds for ubtc. Hicks-neutral tc can arise from changes in $\mathrm{A}_{\mathrm{k}}$, ceteris paribus, proportionate rises in $\theta_{\mathrm{k}}{ }^{\mathrm{s}}$ and $\theta_{\mathrm{k}}^{\mathrm{u}}$; and proportionate falls in $\theta_{\mathrm{k}}{ }^{\mathrm{s}}$ and $\theta_{\mathrm{k}}{ }^{\mathrm{u}}$. In defining factor-biased tc we follow the common assumption that changes in technology parameters are not sufficiently large to reverse the assumed pattern of sectoral factor intensities. In reality, this assumption is supported by the fact that relative factor employments across sectors are very stable over time. Also, note that our discussion of how factor-biased tc relates to technology parameters is for the case of $\sigma>1$. If $\sigma<1$, as equation (3) shows the links between tc and the various parameter changes needs to be reversed. For example, with Leontief technology equation (3) simplifies to $(\mathrm{S} / \mathrm{U})_{\mathrm{k}}=\left(\theta_{\mathrm{k}}{ }^{\mathrm{u}} / \theta_{\mathrm{k}}{ }^{\mathrm{S}}\right)$. Since we define factor-biased tc with respect to $(\mathrm{S} / \mathrm{U})_{\mathrm{k}}$, our analysis below carries through regardless of $\sigma$.
} 


\section{2c Technological Change in a Two-Sector Open Economy With Exogenous Product Prices}

To identify how technological change affects $\left(\mathrm{w}_{\mathrm{S}} / \mathrm{w}_{\mathrm{u}}\right)$ in a two-sector economy, we first assume that product prices $\mathrm{p}_{\mathrm{a}}$ and $\mathrm{p}_{\mathrm{m}}$ are exogenously determined abroad. When both products are made in equilibrium, combining equation (3) with the assumption of zero profits in each sector determines $\left(\mathrm{w}_{\mathrm{s}} / \mathrm{w}_{\mathrm{u}}\right)$ as a function of prices and technology. 6 This gives equation (4).

$$
\left(\frac{w_{s}}{w_{u}}\right)=\left(\frac{\left(\frac{p_{m} A_{m}}{p_{a} A_{a}}\right)^{(\sigma-1)}\left(\theta_{m}{ }^{s}\right)^{\sigma-1}-\left(\theta_{a}{ }^{s}\right)^{\sigma-1}}{\left(\theta_{a}{ }^{u}\right)^{\sigma-1}-\left(\frac{p_{m} A_{m}}{p_{a} A_{a}}\right)^{(\sigma-1)}\left(\theta_{m}{ }^{u}\right)^{\sigma-1}}\right)^{\frac{1}{\sigma-1}}
$$

Equation (4) reveals three important results. First, national factor prices are entirely determined by product prices and technology: national factor supplies do not matter. This result is the Factor-Price-Insensitivity (FPI) theorem (Leamer and Levinsohn (1995)). In different models factor supplies can affect factor prices--e.g., if organized labor defending insider workers generates some intersectoral labor immobility (such that the number of factors exceeds the number of products). In what follows we do not consider these extensions, however. We want to emphasize labor demand in our analysis, and FPI is a maintained assumption in much of the theoretical work we are trying to reconcile. ${ }^{7}$

Second, a rise in $\left(\mathrm{p}_{\mathrm{m}} / \mathrm{p}_{\mathrm{a}}\right)$ raises $\left(\mathrm{w}_{\mathrm{s}} / \mathrm{w}_{\mathrm{u}}\right)$ and vice versa. This is a version of the StolperSamuelson theorem stated in terms of relative factor prices. A rise in the relative price of a product raises the relative wage of the factor employed relatively intensively by that product.

Third, in a two-sector model the factor bias of isolated technological change is totally irrelevant for determining relative factor prices. Instead, it is the sector bias of isolated technological change that matters. Equation (4) shows this. By straightforward differentiation,

\footnotetext{
${ }^{6}$ This assumption of a "diversified" product mix producing both goods seems reasonable for the developed countries we analyze in our empirical work. For the industrial categories in our data, all countries report positive production in all sectors. However, we will consider the possibility that different countries produce different ranges of goods within each industrial category.

${ }^{7}$ In this model the economy absorbs changes in relative labor supply by changing its relative output mix as predicted by the Rybczynski Theorem. Exactly how labor supplies affect wages in different trade models is an extremely important issue in the literature. Deardorff and Haikura (1994), Freeman (1995), Richardson (1995), Johnson (1997), and Topel (1997) provide clear surveys of some important issues related to labor supply.
} 
any technological progress in the machinery sector--i.e., increases in $A_{m}, \theta_{m}{ }^{s}$ or $\theta_{m}{ }^{u}$--raises $\left(\mathrm{w}_{\mathrm{s}} / \mathrm{w}_{\mathrm{u}}\right)$. Conversely, any technological progress in the apparel sector--i.e., increases in $\mathrm{A}_{\mathrm{a}}$, $\theta_{\mathrm{a}}{ }^{\mathrm{s}}$ or $\theta_{\mathrm{a}}{ }^{\mathrm{u}}$--lowers $\left(\mathrm{w}_{\mathrm{s}} / \mathrm{w}_{\mathrm{u}}\right)$. The centrality of sector bias also holds in the case of isolated factor-biased technological progress measured in terms of $(\mathrm{S} / \mathrm{U})_{\mathrm{k}}$. Assuming no technological regress, any change in one sector's $(\mathrm{S} / \mathrm{U})_{\mathrm{k}}$ from some combination of rising $\theta_{\mathrm{k}}{ }^{\mathrm{s}}$ and/or rising $\theta_{\mathrm{k}}{ }^{\mathrm{u}}$ means an increase in the relative wage of the factor employed intensively in sector $\mathrm{k}$. Thus, isolated sbtc or ubtc in machinery (apparel) raises (lowers) $\left(\mathrm{w}_{\mathrm{s}} / \mathrm{w}_{\mathrm{u}}\right) \cdot{ }^{8}$

The intuition is the same in all cases. Technological progress in a sector makes that sector profitable at fixed product prices and initial factor prices. All producers respond to this profit opportunity by trying to expand production in that sector. Hence, national relative labor demand increases for the factor employed relatively intensively in that sector. Given fixed labor supply, relative wages adjust until the profit opportunities are arbitraged away.

Thus the basic conclusion of the one-sector model is completely reversed for a two-sector model with exogenous product prices. In the first case the factorbias of technological change determines changes in relative factor prices; in the second case the sector bias matters.

Since sector bias is central to our paper and may be unfamiliar, it is a conclusion worth emphasizing. The key role played by sector bias in a two-sector model can run counter to the intuition of the one-sector model. For example, how can sbtc in apparel lower $\left(\mathrm{w}_{\mathrm{S}} / \mathrm{w}_{\mathrm{u}}\right)$ ? To clarify matters it might help to contrast the conclusion from the one-sector model. In the onesector model, sbtc in apparel does raise $\left(\mathrm{w}_{\mathrm{S}} / \mathrm{w}_{\mathrm{U}}\right)$ to "choke off" the increased demand for skilled workers and thus equalize labor demand and supply. But by assumption, in the onesector model technology changes cannot change relative profitability across sectors.

In a two-sector model these changes in relative profitability are central. In response to sbtc in apparel, producers in all sectors try to make more apparel. With constant national factor supply, factors move out of machinery into apparel. Demand nationwide for the factor

\footnotetext{
${ }^{8}$ If technological regress is possible then changes in $(\mathrm{S} / \mathrm{U})_{\mathrm{k}}$ do not have clear wage implications. For example, machinery-biased isolated sbtc can lower $\left(\mathrm{w}_{\mathrm{S}} / \mathrm{w}_{\mathrm{u}}\right)$ if the rise in $(\mathrm{S} / \mathrm{U})_{\mathrm{m}}$ is caused by a decline in $\theta_{\mathrm{m}}{ }^{\mathrm{u}}$. Also, the comparative-statics from equation (4) all hold if $\sigma<1$--e.g., if technology is Leontief.
} 
employed relatively intensively in apparel--unskilled labor--increases relative to national demand for skilled labor. This demand shift lowers $\left(\mathrm{w}_{\mathrm{S}} / \mathrm{w}_{\mathrm{U}}\right)$ until the initial profit opportunity in apparel is completely arbitraged away. Notice why the intuition of the one-sector model no longer applies. If $\left(\mathrm{w}_{\mathrm{S}} / \mathrm{w}_{\mathrm{u}}\right)$ rises then zero profits are not restored in both sectors--in fact, a higher $\left(\mathrm{w}_{\mathrm{S}} / \mathrm{w}_{\mathrm{U}}\right)$ only increases the initial profit opportunity in apparel.

Shifting analysis from isolated to pervasive technological change clarifies why neither the pervasiveness nor the acceleration of technological change alone can explain rising wage inequality. Consider pervasive sbtc in the case of increases in both $\theta_{\mathrm{a}}{ }^{\mathrm{s}}$ and $\theta_{\mathrm{m}}{ }^{\mathrm{s}}$. In equation (4) the higher $\theta_{\mathrm{a}}{ }^{\mathrm{s}}$ lowers $\left(\mathrm{w}_{\mathrm{s}} / \mathrm{w}_{\mathrm{u}}\right)$ while the higher $\theta_{\mathrm{m}}{ }^{\mathrm{s}}$ raises $\left(\mathrm{w}_{\mathrm{s}} / \mathrm{w}_{\mathrm{u}}\right)$. The net effect of these pervasive changes is unclear. An acceleration of pervasive technological change yields the same result. For example, an acceleration of pervasive sbtc might mean a quickening of the rate of increase in both $\theta_{\mathrm{a}}{ }^{\mathrm{s}}$ and $\theta_{\mathrm{m}}{ }^{\mathrm{s}}$. In equation (4) acceleration means that both components of the numerator rise more in the current period than in some previous period. But the net effect on the numerator and thus the skill premium is unclear. As with pervasiveness, acceleration alone can generate any change in relative wages.

That sector bias drives relative-wage changes through changes in relative profitability has been analyzed in the literature in the case of isolated technical change. But does the sector bias of pervasive technical change determine relative-wage changes? Again, this is a key question because empirical evidence indicates that technical change has indeed been pervasive in many countries in recent decades. The answer turns out to be ambiguous. Even if pervasive factorbiased tc is known to have a sector bias, this information alone is not sufficient to determine wage changes. Consider the case of machinery-biased pervasive sbtc, a rise in $(\mathrm{S} / \mathrm{U})_{\mathrm{m}}$ that exceeds the rise in $(\mathrm{S} / \mathrm{U})_{\mathrm{a}}$. This means that the rise in $\left(\theta_{\mathrm{m}}{ }^{\mathrm{s}} / \theta_{\mathrm{m}}{ }^{\mathrm{u}}\right)$ exceeds the rise in $\left(\theta_{\mathrm{a}}{ }^{\mathrm{s}} / \theta_{\mathrm{a}}{ }^{\mathrm{u}}\right)$. Inspection of equation (4) reveals that this information alone cannot determine changes in $\left(\mathrm{w}_{\mathrm{S}} / \mathrm{w}_{\mathrm{u}}\right)$. Each change in $(\mathrm{S} / \mathrm{U})_{\mathrm{k}}$ signals a new profit-maximizing relative-employment mix within each sector $\mathrm{k}$. But this conveys no information on the change in relative profitability across sectors which governs wage changes. Additional information about the bias parameters 
is required to determine relative-profitability changes. For example, if rises in $\theta_{\mathrm{k}}{ }^{\mathrm{u}}$ are proportionate across sectors then machinery-biased pervasive sbtc initially makes machinery relatively more profitable and thus raises $\left(\mathrm{w}_{\mathrm{S}} / \mathrm{w}_{\mathrm{u}}\right)$. In general, the sector bias of pervasive sbtc does indicate the direction of wage changes if more extensive skill-upgrading in a sector generates greater cost reductions in that sector. ${ }^{9}$

Figure 1 summarizes equation (4) in $\left[\left(\mathrm{p}_{\mathrm{m}} / \mathrm{p}_{\mathrm{a}}\right),\left(\mathrm{w}_{\mathrm{s}} / \mathrm{w}_{\mathrm{u}}\right)\right]$ space. The upward-sloping SS curve displays the Stolper-Samuelson relationship between exogenous $\left(\mathrm{p}_{\mathrm{m}} / \mathrm{p}_{\mathrm{a}}\right)$ and endogenous $\left(\mathrm{w}_{\mathrm{s}} / \mathrm{w}_{\mathrm{u}}\right)$ given technology. Any isolated technological progress in machinery (apparel) shifts the SS curve to the right (left), thereby raising (lowering) $\left(\mathrm{w}_{\mathrm{s}} / \mathrm{w}_{\mathrm{u}}\right)$ at constant $\left(\mathrm{p}_{\mathrm{m}} / \mathrm{p}_{\mathrm{a}}\right)$.

Figure 1

Relative Factor Prices in an Open Economy With Exogenous Product Prices

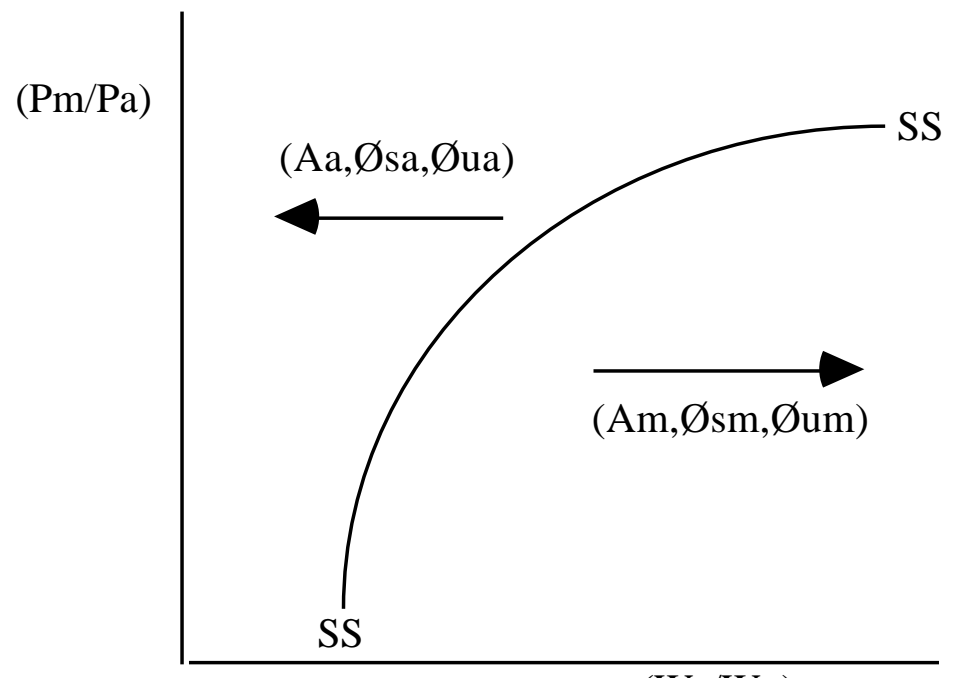

$(\mathrm{Ws} / \mathrm{Wu})$

Figure 1 summarizes this section's three key points. First, the sector bias of any tc (i.e., the direction of shift in SS) is critical to signing changes in $\left(\mathrm{w}_{\mathrm{s}} / \mathrm{w}_{\mathrm{u}}\right)$. Second, neither pervasive nor accelerating sbtc is sufficient to raise wage inequality (because pervasiveness shifts SS in both directions). Third, the sector bias of pervasive sbtc determines changes in $\left(\mathrm{w}_{\mathrm{s}} / \mathrm{w}_{\mathrm{u}}\right)$ if

\footnotetext{
${ }^{9}$ It is important to stress why isolated and pervasive factor-biased tc are so different. Any factor-biased tc alters the relative profitability of skilled and unskilled employment within the sector(s) enjoying the change. If this tc is isolated it also unambiguously alters profitability across sectors. Almost all the theoretical literature has confined itself to this case. But if the factor-biased tc is pervasive, information on within-sector relative profitability alone is not enough to determine shifts in profitability across sectors.
} 
more extensive skill-upgrading in a sector means greater cost reductions in that sector (and thus a sector-determined shift in SS).

\section{2d Technological Change in a Two-Sector Open Economy With Endogenous Product Prices}

The Direct and Indirect Effects of Technological Change on Relative Wages

We now consider the more general case where technological progress can affect $\left(\mathrm{p}_{\mathrm{m}} / \mathrm{p}_{\mathrm{a}}\right)$. We do this by assuming that home and foreign share identical production technologies. Innovation in one country is thus worldwide innovation that affects world supply and thus product prices. Alternatively, we could assume local innovation where home is sufficiently large that its supply affects world prices. Our analysis will show that in many cases the sector bias of technical change is still the key determinant of changes in $\left(\mathrm{w}_{\mathrm{S}} / \mathrm{w}_{\mathrm{u}}\right)$. In section $2 \mathrm{e}$ we will relate our analysis to other studies.

To proceed we express world relative output demand and supply as functions of product prices, tastes, production technology, and factor endowments. With the assumption of homothetic preferences, world relative demand depends on just utility parameters and product prices. For example, with Cobb-Douglas utility where $\alpha$ is the constant share of expenditure spent on manufactures, demand can be written as follows.

$$
\left(\frac{\boldsymbol{Y}_{\boldsymbol{m}}}{\boldsymbol{Y}_{\boldsymbol{a}}}\right)^{\boldsymbol{D}}=\left(\frac{\alpha}{1-\alpha}\right)\left(\frac{\boldsymbol{P}_{\boldsymbol{a}}}{\boldsymbol{P m}}\right)
$$

World relative supply depends on prices, technology, and endowments. Define E to be the world endowment of skilled labor relative to unskilled labor (assumed to be fully employed). Because production technologies are identical worldwide, combining E with equations (1), (2), and zero profits yields an expression for world relative output supply, $\left(\mathrm{Y}_{\mathrm{m}} / \mathrm{Y}_{\mathrm{a}}\right)^{\mathrm{s}}$ : 


$$
\left(\frac{Y_{m}}{Y_{a}}\right)^{S}=\left(\frac{E-(S / U)_{a}}{(S / U)_{m}-E}\right)\left(\frac{A_{m}}{A_{a}}\right)^{I-\sigma}\left(\frac{p_{m}}{p_{a}}\right)^{-\sigma}
$$

If production technology is Leontief as in Krugman (1995) and Davis (1997) then $(\mathrm{S} / \mathrm{U})_{\mathrm{k}}$ is determined entirely by technology parameters; also, $\left(\mathrm{p}_{\mathrm{m}} / \mathrm{p}_{\mathrm{a}}\right)$ drops out of equation (6). In this case $\left(\mathrm{Y}_{\mathrm{m}} / \mathrm{Y}_{\mathrm{a}}\right)^{\mathrm{s}}$ is a function of just technology and endowments. In the more general CES case, however, $(\mathrm{S} / \mathrm{U})_{\mathrm{k}}$ also depends on endogenous relative factor prices (by equation (3))--which in turn depend on technology and product prices (by equation (4)). In this case, equations (3) and (4) must be substituted into (6) to express $\left(\mathrm{Y}_{\mathrm{m}} / \mathrm{Y}_{\mathrm{a}}\right)^{\mathrm{s}}$ in terms of product prices, technology, and endowments. In this case $\left(\mathrm{Y}_{\mathrm{m}} / \mathrm{Y}_{\mathrm{a}}\right)^{\mathrm{s}}$ is increasing in $\left(\mathrm{p}_{\mathrm{m}} / \mathrm{p}_{\mathrm{a}}\right)$.

Any technical change shifts $\left(\mathrm{Y}_{\mathrm{m}} / \mathrm{Y}_{\mathrm{a}}\right)^{\mathrm{s}}$ according to equation (6). This supply shift and $\left(Y_{m} / Y_{a}\right)^{D}$ in equation (5) determine the change in $\left(\mathrm{p}_{\mathrm{m}} / \mathrm{p}_{\mathrm{a}}\right)$. This price change moves relative wages in equation (4). Thus the total effect of technological change on $\left(\mathrm{w}_{\mathrm{s}} / \mathrm{w}_{\mathrm{u}}\right)$ can be decomposed into a direct effect where $\left(\mathrm{p}_{\mathrm{m}} / \mathrm{p}_{\mathrm{a}}\right)$ is fixed as in section $2 \mathrm{c}$ and an indirect effect working through changes in $\left(\mathrm{p}_{\mathrm{m}} / \mathrm{p}_{\mathrm{a}}\right)$ as just described.

\section{The Effect of Technological Change on Relative Output Supply}

To calculate the indirect effect of technological change on $\left(\mathrm{w}_{\mathrm{s}} / \mathrm{w}_{\mathrm{u}}\right)$ it is helpful to calculate first the effect on $\left(\mathrm{Y}_{\mathrm{m}} / \mathrm{Y}_{\mathrm{a}}\right)^{\mathrm{s}}$. Differentiating equation (6) shows that for $\sigma>1,\left(\mathrm{Y}_{\mathrm{m}} / \mathrm{Y}_{\mathrm{a}}\right)^{\mathrm{s}}$ rises for any increase in $A_{m}, \theta_{m}{ }^{s}$ or $\theta_{m}{ }^{u}$, and it falls for any increase in $A_{a}, \theta_{a}{ }^{s}$ or $\theta_{a}{ }_{a}$. Thus, any isolated technology improvement in machinery (apparel) raises (lowers) $\left(\mathrm{Y}_{\mathrm{m}} / \mathrm{Y}_{\mathrm{a}}\right)^{\mathrm{s}}$.

The intuition of this result can be seen in equation (6). First, $A_{m}$ and $A_{a}$ change $\left(Y_{m} / Y_{a}\right)^{s}$ in analogous fashion to how $\mathrm{p}_{\mathrm{m}}$ and $\mathrm{p}_{\mathrm{a}}$ change $\left(\mathrm{Y}_{\mathrm{m}} / \mathrm{Y}_{\mathrm{a}}\right)^{\mathrm{s}}$. The four biased technology parameters change $\left(\mathrm{Y}_{\mathrm{m}} / \mathrm{Y}_{\mathrm{a}}\right)^{\mathrm{s}}$ through both a direct and an indirect channel. The direct channel is, from equation (6), movements in $\left(\mathrm{Y}_{\mathrm{m}} / \mathrm{Y}_{\mathrm{a}}\right)^{\mathrm{s}}$ at initial factor prices due to a shift in $(\mathrm{S} / \mathrm{U})_{\mathrm{k}}$ in the sector k enjoying the technology improvement. In this case, sbtc (ubtc) in either sector releases $\mathrm{U}(\mathrm{S})$ into the economy. These released workers are re-employed in the sector which uses them relatively intensively, namely, sector A (M). This tends to decrease (increase) 
$\left(\mathrm{Y}_{\mathrm{m}} / \mathrm{Y}_{\mathrm{a}}\right)^{\mathrm{s}}$. The indirect channel arises because technological change induces factor-price changes and thus changes in $(\mathrm{S} / \mathrm{U})_{\mathrm{j}}$ in both sectors. Both sectors respond to the rise (fall) in $\left(\mathrm{w}_{\mathrm{s}} / \mathrm{w}_{\mathrm{u}}\right)$ by substituting away from the rising-price factor and thus reducing (increasing) $(\mathrm{S} / \mathrm{U})_{\mathrm{k}}$. With an increase in either $\theta_{\mathrm{m}}{ }^{\mathrm{u}}$ or $\theta_{\mathrm{a}}{ }^{\mathrm{s}}$, both channels work in the same direction such that $\left(\mathrm{Y}_{\mathrm{m}} / \mathrm{Y}_{\mathrm{a}}\right)^{\mathrm{s}}$ rises and falls, respectively. With an increase in either $\theta_{\mathrm{m}}{ }^{\mathrm{s}}$ or $\theta_{\mathrm{a}}{ }^{\mathrm{u}}$, however, the two channels work in opposite directions. In these two cases intuition alone can't determine the change in $\left(\mathrm{Y}_{\mathrm{m}} / \mathrm{Y}_{\mathrm{a}}\right)^{\mathrm{s}}$, but it can be shown that the indirect channel dominates the direct channel in these other two cases. Thus an increase in $\theta_{\mathrm{m}}{ }^{\mathrm{s}}\left(\theta_{\mathrm{a}}{ }^{\mathrm{u}}\right)$ raises (lowers) $\left(\mathrm{Y}_{\mathrm{m}} / \mathrm{Y}_{\mathrm{a}}\right)^{\mathrm{s}}$.

The Total Effect of Technological Change on Relative Wages

What is the total effect of technological change on relative wages? Given relative-output demand, the shifts in $\left(\mathrm{Y}_{\mathrm{m}} / \mathrm{Y}_{\mathrm{a}}\right)^{\mathrm{s}}$ imply that $\left(\mathrm{p}_{\mathrm{m}} / \mathrm{p}_{\mathrm{a}}\right)$ falls (rises) in response to any isolated technology improvement in the machinery (apparel) sector. From equation (4), any isolated technology improvement in machinery tends to lower $\left(\mathrm{w}_{\mathrm{s}} / \mathrm{w}_{\mathrm{u}}\right)$ by lowering $\left(\mathrm{p}_{\mathrm{m}} / \mathrm{p}_{\mathrm{a}}\right)$--and vice versa. This is simply an application of the Stolper-Samuelson theorem.

The total effect of this indirect effect combined with the direct effect is set out in Figure 2.

Figure 2

$\underline{\text { Relative Factor Prices in an Open Economy With Endogenous Product Prices }}$

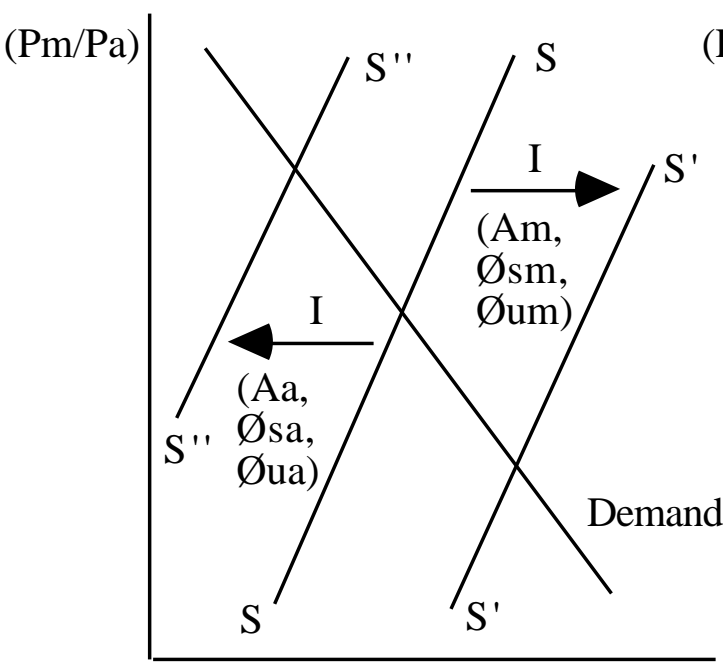

$(\mathrm{Ym} / \mathrm{Ya})$

World Relative Output
$(\mathrm{Pm} / \mathrm{Pa})$

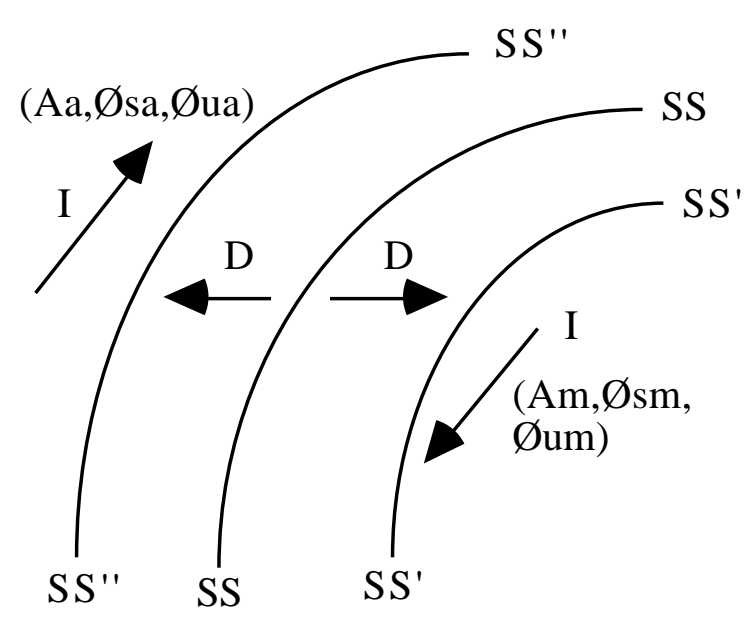

(Ws/Wu)

National Relative Wages

The direct effect of any technological change on relative wages is shown in the right panel by 
the "D" arrows as a shift in the position of the SS schedule. In the left panel technological change shifts the world relative supply schedule as indicated by the "I" arrows. This changes world relative prices, and the indirect effect of this on national relative wages is indicated by "I" arrows in the right panel as a movement along the new SS schedule. In every case the direct effect at initial product prices tends to be offset by the indirect effect of changed product prices. Hence with endogenous product prices the total effect of isolated technological change on relative factor prices is ambiguous in all cases.

What about pervasive technical change? The ambiguity of the previous section with fixed $\left(\mathrm{p}_{\mathrm{m}} / \mathrm{p}_{\mathrm{a}}\right)$ carries over to this case of endogenous $\left(\mathrm{p}_{\mathrm{m}} / \mathrm{p}_{\mathrm{a}}\right)$. The direct effect on wages of pervasive technical progress is unclear, as before. The indirect effect is also unclear.

Cases in Which the Sector Bias of Technological Change Determines Relative Wages

The centrality of sector bias seems weakened with endogenous product prices. However, we argue that in the following three cases, even with endogenous product prices the sector bias of technological change will still be the key determinant of changes in relative factor prices.

\section{Case \#1: Sufficiently Elastic Output Demand}

If relative-output demand is sufficiently elastic then the indirect effect of technologyinduced product-price changes are "sufficiently small" (in figure 2 this means "sufficiently flat" demand curves). As Krugman (1995) points out, the elasticity of demand depends critically on the degree of sectoral aggregation. For the disaggregated tradable-sectors data we use below, we think the elastic case is likely to be more relevant.

\section{Case \#2: Sufficiently Small Factor Substitutability in Production}

Case \#2 reduces $\sigma$, the degree of factor substitutability. Since Leontief technology $(\sigma=0)$ has been extensively used in the literature, we analyze this scenario. The key effect of reducing $\sigma$ is to alter the impact of technological change on $\left(\mathrm{Y}_{\mathrm{m}} / \mathrm{Y}_{\mathrm{a}}\right)^{\mathrm{s}}$. Recall from equation (6) that with $\sigma>0$ any factor-biased technical progress affects $\left(\mathrm{Y}_{\mathrm{m}} / \mathrm{Y}_{\mathrm{a}}\right)^{\mathrm{s}}$ through both a direct and an indirect channel. With Leontief technology, however, there is no indirect channel because there is no within-sector factor substitution from factor price changes. 
Very different results are obtained for the two ceteris paribus cases--an increase in either $\theta_{\mathrm{m}}{ }^{\mathrm{s}}$ or $\theta_{\mathrm{a}}{ }^{\mathrm{u}}$--where the direct and indirect channels previously offset each other. With $\sigma=0$, higher $\theta_{\mathrm{m}}{ }^{\mathrm{s}}\left(\theta_{\mathrm{a}}{ }^{\mathrm{u}}\right)$ lowers (raises) $\left(\mathrm{Y}_{\mathrm{m}} / \mathrm{Y}_{\mathrm{a}}\right)^{\mathrm{s}}$. In turn, lower (higher) $\left(\mathrm{Y}_{\mathrm{m}} / \mathrm{Y}_{\mathrm{a}}\right)^{\mathrm{s}}$ raises $\left(\mathrm{p}_{\mathrm{m}} / \mathrm{p}_{\mathrm{a}}\right)$ and thus indirectly raises $\left(\mathrm{w}_{\mathrm{s}} / \mathrm{w}_{\mathrm{u}}\right)$. Overall, then, for these two types of technological change the direct and indirect effects on wages now work in the same direction: sbtc (ubtc) in machinery (apparel) unambiguously raises (lowers) $\left(\mathrm{w}_{\mathrm{s}} / \mathrm{w}_{\mathrm{u}}\right)$. Figure 3 summarizes these results to help contrast them with the earlier results in Figure 2 (recall from equation (6) that the Leontief $\left(\mathrm{Y}_{\mathrm{m}} / \mathrm{Y}_{\mathrm{a}}\right)^{\mathrm{s}}$ schedule does not depend on $\left.\left(\mathrm{p}_{\mathrm{m}} / \mathrm{p}_{\mathrm{a}}\right)\right)$. In Figure 2 sector bias determines shifts in $\left(\mathrm{Y}_{\mathrm{m}} / \mathrm{Y}_{\mathrm{a}}\right)^{\mathrm{s}}$; in Figure 3 it is the factor bias.

Figure 3

Relative Factor Prices in an Open Economy With Endogenous Product Prices: The Case of Leontief Production Technologies

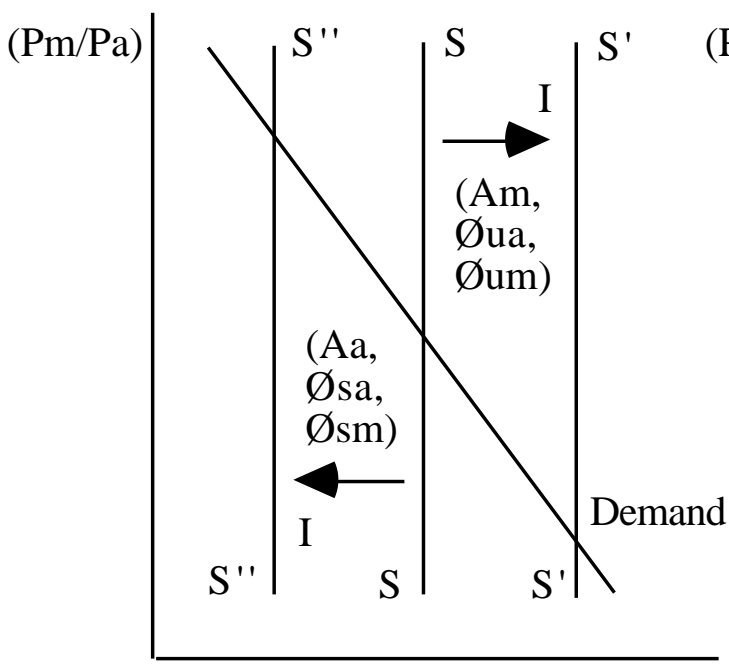

$(\mathrm{Ym} / \mathrm{Ya})$

World Relative Output

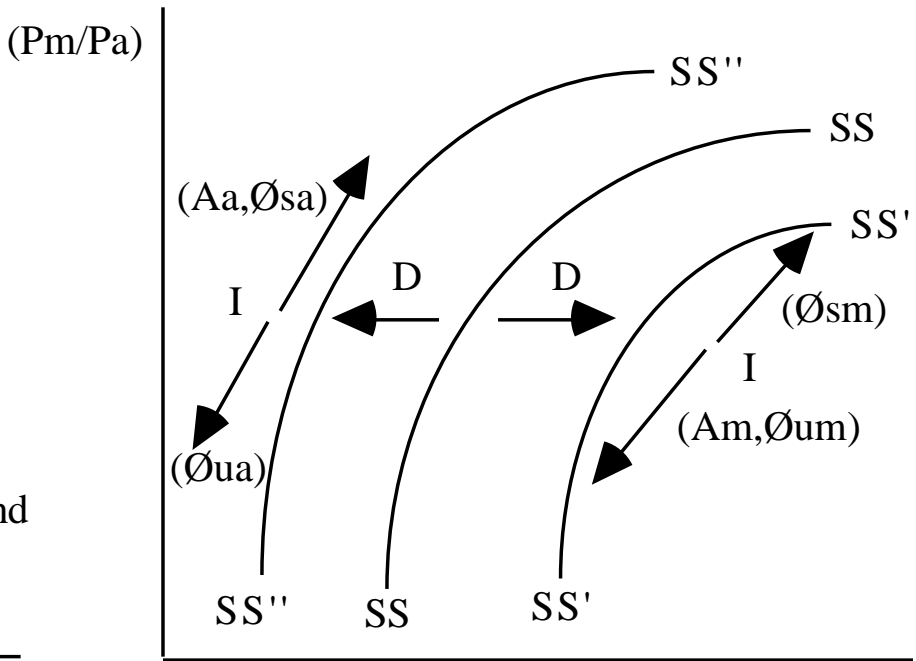

$(\mathrm{Ws} / \mathrm{Wu})$ National Relative Wages

Thus the smaller is $\sigma$ the more likely it is that some kinds of factor-biased technological change have reinforcing direct and indirect effects on relative wages. That is, the smaller is $\sigma$ the more the sector bias of technological change matters for relative factor prices. ${ }^{10}$

\section{Case \#3: Existence of a Nontraded Sector}

Finally, extending the model to include nontraded goods provides another plausible reason why the sector bias is crucial even with endogenous product prices. As Leamer (1996, p. 25)

\footnotetext{
${ }^{10}$ From figure 3, note that pervasive sbtc--independent of its sector bias and assuming no technical regress-unambiguously shift $\mathrm{S}$ to $\mathrm{S}^{\prime \prime}$. Hence the direct effect of pervasive sbtc is unclear but its indirect effect raises inequality.
} 
notes in passing, the reason is that technological change in the tradables sector induces smaller product-price changes the more the nontraded sector can absorb factors released by technology.

To see this, reinterpret $\mathrm{E}$ as the world relative endowment available for tradables production. The presence of a nontraded sector means that factors released by technological progress in tradables can migrate into nontradables and thereby change E. Technology's effect on $\left(\mathrm{Y}_{\mathrm{m}} / \mathrm{Y}_{\mathrm{a}}\right)^{\mathrm{s}}$ and thus on $\left(\mathrm{p}_{\mathrm{m}} / \mathrm{p}_{\mathrm{a}}\right)$ is potentially dampened. For example, consider the case of sbtc in apparel. If this increase in $(\mathrm{S} / \mathrm{U})_{\mathrm{a}}$ releases unskilled labor into nontradables then $\mathrm{E}$ rises. In equation (6), changing both $(\mathrm{S} / \mathrm{U})_{\mathrm{a}}$ and $\mathrm{E}$ can mean little or no change in $\left(\mathrm{Y}_{\mathrm{m}} / \mathrm{Y}_{\mathrm{a}}\right)^{\mathrm{s}}$. If $\left(Y_{m} / Y_{a}\right)^{s}$ shifts very little then so does $\left(p_{m} / p_{a}\right)$. In this case the direct effect of the rise in $\theta_{a}{ }^{s}$-that is, its sector bias--matters for relative factor prices.

In reality, workers moving from tradables to nontradables seems important. For example, between 1979 and 1989 both U.S. and U.K. manufacturing lost more than two million jobs while the national share of nontradable employment rose.

\section{2e Technological Change and Relative Factor Prices: Relating Our Results To the Literature}

How does our main conclusion relate to the existing literature? First, it is important to note that most work considers only isolated technical change. In the case of fixed product prices, there is widespread agreement that the sector bias of technological change determines changes in relative factor prices. See Findlay and Grubert (1959) and Krauss and Johnson (1974) for two of the earliest statements of this result and, more recently, Krugman (1995), Richardson (1995), Wood (1995), Leamer (1996), Berman, et al (1997), and Davis (1997).

Much of the disagreement involves how technological change affects world product prices through changes in world product supplies. Some papers do not consider this case in much detail. Bhagwati and Dehejia (1994), Richardson (1995), and Wood (1995) do not focus on how technology can change product prices. Leamer (1996) allows an empirical link from technology to prices but provides no formal model. Findlay and Grubert (1959) and Krauss and Johnson (1974) obtain the same qualitative world-supply shifts as we do. But they do not 
link the ambiguous cases to factor substitutability, nor do they analyze how these supply shifts affect factor prices.

Among the studies that do address endogenous product prices, Baldwin and Cain (1997) focus on hntc in machinery, and they also find an unclear net effect because of offsetting direct and indirect effects. Davis (1997) analyzes isolated technical change with Leontief technology and (briefly) with some factor substitutability. In all his cases our results match his.

Our results differ from those of Krugman (1995) who, like Davis, works with Leontief technologies. He first claims that with endogenous product prices, isolated hntc does not affect relative factor prices. Figure 3 shows that this is possible if the direct and indirect effects just offset each other. But this is not a necessary outcome, even with Leontief technology. Second, Krugman claims that with endogenous product prices the factor bias of technological change determines the effect on relative wages: any sbtc (ubtc) raises (lowers) $\left(\mathrm{w}_{\mathrm{s}} / \mathrm{w}_{\mathrm{u}}\right)$. Figure 3 shows this prediction need not be true for sbtc in apparel and ubtc in machinery. In all cases Krugman correctly identifies the indirect effects, but in these two cases he seems to ignore the offsetting direct effects. Third, Krugman claims that relaxing the Leontief assumption still yields the endogenous-price results of hntc not affecting $\left(\mathrm{w}_{\mathrm{s}} / \mathrm{w}_{\mathrm{u}}\right)$ and sbtc raising $\left(\mathrm{w}_{\mathrm{S}} / \mathrm{w}_{\mathrm{u}}\right)$. Our analysis summarized in figure 2 shows these claims are possibly true but not necessarily true.

Only two papers have considered pervasive technical change. Baldwin and Cain (1997) consider "uniform" sbtc defined as sbtc in both sectors that does not change relative wages at given relative prices. We prefer our definitions of sector bias since they are in terms of technical primitives, not endogenous wages or product prices. Berman, et al (1997) offer "pervasive, sector-neutral sbtc" as a possible explanation for rising wage inequality. Evaluating this claim is difficult because they never define this kind of technical change. Under our definition this kind of progress has unclear wage effects even with fixed product prices. With flexible prices, figures 2 and 3 show that the indirect wage effect of this progress raises inequality only in the Leontief case--but the direct effect of pervasive tc is ambiguous, so the overall effect on wages is ambiguous. 


\section{2f Summary}

Our main theoretical conclusion is that in many cases it is the sector bias of technological change that matters for relative factor prices. This is because with multiple sectors, relativewage changes are driven by relative profitability across sectors. Thus the sector where technological change occurs is critical.

The crucial role of sector bias unambiguously applies for the case of isolated technical change in a two-sector open economy facing exogenous product prices. With endogenous product prices and sufficient within-industry substitutability, the total effect of all technological changes on relative factor prices is ambiguous. However, even with endogenous product prices in many cases relative factor prices still depend on the sector bias. We reviewed three such situations.

- Sufficiently elastic output demand

- Sufficiently small factor substitutability in production

- Existence of a nontraded sector

An important contribution of our theoretical analysis has been to demonstrate the ambiguities of the empirically relevant case of pervasive sbtc. The sector bias of pervasive sbtc alone does not predict the net change in relative profitability across sectors. Thus in general, the sector bias of pervasive sbtc is only suggestive of the direction of relative-wage changes. But if more extensive skill-upgrading in a sector generates greater cost reductions in that sector, then the sector bias of pervasive sbtc does indicate the direction of wage changes.

\section{Empirical Plan and Measuring the Sector Bias of SBTC}

\section{$3 a$ Empirical Plan}

We test our sector-bias hypothesis for sbtc only. As discussed in this paper's introduction there is a large literature documenting the pervasiveness of sbtc and exploring its acceleration as well. However, we are unaware of any work on the sector bias of sbtc. Given the strong interest in sbtc and the total lack of evidence on its sector bias, we think this issue merits empirical analysis. Of course, this analysis is subject to our caveat that the sector bias of pervasive sbtc is only suggestive of the direction of relative-wage changes. Only if more 
extensive sbtc in a sector implies greater cost reductions in that sector does the sector bias predict the direction of wage changes. For empirical studies of the sector bias of total factor productivity (tfp)--i.e., of the net effect of all kinds of technological change--see Leamer (1996) and Feenstra and Hanson (1997). We will relate our results for sbtc to theirs.

Given this focus on sbtc, we briefly preview how we apply our model to the data. The model's most important insight is the sector bias of sbtc suggests the factor-price adjustments necessary to restore zero profits in all sectors. To test this sector-bias hypothesis first we construct measures of sectoral sbtc and then we examine the wage changes they imply.

\section{$3 b$ Measuring the Sector Bias of sbtc}

\section{Data Sources}

As will be discussed below, our empirical analysis requires sectoral measures of sbtc, skilled/unskilled employment, and cost shares for all factors employed. Most of our data cover manufacturing only because we do not have sufficient data for services. However, because manufacturing sectors are tradable these data most closely match our model.

For the United States we use the National Bureau of Economic Research's Productivity Data Base, an industry-year panel of 450 four-digit U.S. SIC sectors. We also use sector data (both manufacturing and services) from Autor, et al (1997), Berman, et al (1994), and Mishel and Bernstein (1996) for measures of computerization that are regarded as plausible correlates of sbtc. For the United Kingdom we use a sector-year panel of 125 three-digit sectors based on the U.K. Census of Production compiled by Oulton and O'Mahoney (1996). We also use the U.K. ARD database to construct a computerization measure at the four-digit U.K. SIC level. Data for our eight other countries are the United Nations General Industrial Data Base. ${ }^{11}$

Most of our data classify workers as nonproduction and production. We define the former to be skilled and the latter to be unskilled. Berman, et al (1994) document for the United States

\footnotetext{
${ }^{11}$ We are very grateful to Nick Oulton for providing us with the U.K. panel data. The Oulton/O'Mahoney data runs 1954 to 1986 at 5 year intervals. In some cases we use their data for the 1970s and Census data for the 1980s (the 1980s data contain fewer sectors because of a major classification change). For providing us with the data on U.S. computerization we are extremely grateful to the various authors. For providing us with the U.N. data we are extremely grateful to Eli Berman.
} 
that employment trends for this job-classification measure track quite closely employment trends measured by the white-collar/blue-collar job classification--which in turn closely reflects the college/high-school classification.

\section{Measure of sbtc Derived From Translog Production Technology}

Following Binswanger (1974), Berndt and Wood (1982), and Berman, et al (1994), we measure sectoral sbtc as the change in skilled labor's cost share that is not explained by factorprice changes. We construct this measure by assuming firms minimize labor costs according to a restricted translog cost function with constant returns to scale and fixed capital. ${ }^{12}$ From this cost function one can derive a set of cost-share equations, one per labor type, which relate the level change in each factor's cost share over some time period to log changes in factor prices, capital, and output. If we then pool across all sectors we get the set of cost-share equations for nonproduction labor as follows:

$$
\Delta \mathrm{S}_{\mathrm{k}}=a_{0}+a_{1} \Delta \log \left(w_{s} / w_{u}\right)_{k}+a_{2} \Delta \log (K / Y)_{k}+\varepsilon_{k}
$$

where $\mathrm{k}$ indexes sectors, $\Delta \mathrm{S}_{\mathrm{k}}$ is the level change in the nonproduction-labor share of the total wage bill, $\mathrm{K}$ is capital, $\mathrm{Y}$ is real value-added output, and $\varepsilon_{\mathrm{k}}$ is an additive error term.

For each country, if one pools all sectors and estimates equation (7) for changes over some time period, then the variation in $S_{k}$ not explained by changes in factor prices and factor quantities is attributed to technological change.. The parameter $a_{0}$ measures the factor bias of technological change that is common to all sectors, and the quantity $\left(\mathrm{a}_{\mathrm{o}}+\varepsilon_{\mathrm{k}}\right)$ measures the factor bias of technological change particular to sector $\mathrm{k}$. When $\left(\mathrm{a}_{\mathrm{o}}+\varepsilon_{\mathrm{k}}\right)$ is positive technological change is skill-biased in sector $\mathrm{k}$. The larger is $\left(\mathrm{a}_{\mathrm{o}}+\varepsilon_{\mathrm{k}}\right)$ in some sector $\mathrm{k}$, the more concentrated sbtc is in that sector. Thus the full $\mathrm{K} x 1$ vector of $\left(\mathrm{a}_{\mathrm{o}}+\varepsilon_{\mathrm{k}}\right)$ captures the pervasiveness sbtc.

There are three important issues to mention regarding this measure of sbtc. First is our interpretation of sectors for which $\left(\mathrm{a}_{\mathrm{o}}+\varepsilon_{\mathrm{k}}\right)$ is negative. With only skilled and unskilled labor as

12 The advantage of the translog functional form is it imposes fewer restrictions on factor substitutability than either CES, Cobb-Douglas, or Leontief production technologies. The restriction for fixed capital is imposed, following Berman, et al (1994), because our data do not report capital's factor price. 
the flexible factors in equation (7), the cost shares of these two factors must sum to unity so a sector can have either sbtc or ubtc, but not both. Thus by construction, a negative $\left(\mathrm{a}_{\mathrm{o}}+\varepsilon_{\mathrm{k}}\right)$ indicates sector $\mathrm{k}$ enjoyed ubtc, not sbtc. This empirical constraint parallels our model with only two factors. When the factor bias of technical change is measured by changes in $(\mathrm{S} / \mathrm{U})_{\mathrm{k}}$ conditional on wage changes, sector k can enjoy sbtc or ubtc (or neither) but not both. With a more general specification of equation (7) where firms minimize costs over several factors this need not be the case--a sector could enjoy both sbtc and ubtc. We treat sectors for which $\left(\mathrm{a}_{\mathrm{o}}+\varepsilon_{\mathrm{k}}\right)$ is negative two different ways. One is to measure their sbtc as $\left(\mathrm{a}_{\mathrm{o}}+\varepsilon_{\mathrm{k}}\right)$ and to say these sectors experienced less extensive sbtc--so much so that their $\varepsilon_{\mathrm{k}}$ was largely negative. The other is to measure their sbtc as zero, and to say these sectors experienced no sbtc at all. We report results using the first option, but the other option yields qualitatively similar results. ${ }^{13}$

A second important point is that our sbtc measures from equation (7) are very robust to a number of specification choices. First, estimates are robust to excluding wages. ${ }^{14}$ Second, estimates are also robust to disaggregating capital between plant and equipment (only the U.S. data permit this distinction). Third, we estimated equation (7) by OLS and by weighted least squares using sector employment or output as weights; we found similar results both ways. Fourth, we varied the starting and ending years for decades when analyzing sbtc over decades. The sample correlations among the different $\left(\mathrm{a}_{\mathrm{o}}+\varepsilon_{\mathrm{k}}\right)$ vectors obtained from different specifications are high--usually above 0.9 .

Our final point is that our translog sbtc measure is highly correlated with other productionderived sbtc measures. We also constructed a measure derived from a CES production

\footnotetext{
13 With adequate price data for capital (and other factors) we would estimate a system of cost-share equations both to relax the restriction that ubtc implies no sbtc and to gain efficiency by imposing cross-equation symmetry restrictions. Unfortunately, because of data limitations this system estimation is not possible. Even so, a moreextensive system would still not measure the sector cost reductions induced by sbtc.

${ }^{14}$ This follows Berman, et al (1994), who argue that cross-sectional differences in wage changes might reflect sectors employing different skill mixes of labor. Our theory with perfect interindustry factor mobility predicts no such crosssectional differences. Also, because not all of our data contain data on real value added, where necessary we follow Berman, et al, in using real value of shipments. Finally, notice that because the parameters $\mathrm{a}_{1}$ and $\mathrm{a}_{2}$ are not sector specific, pooling imposes the restriction that $S_{n p}$ responds the same in every sector to changes in factor prices and quantities. We follow Berman, et al, in imposing this restriction. Where data was available, for our sample of ten countries we also estimated equation (7) for each sector pooling industries across countries. This yielded qualitatively similar results.
} 
technology employing just skilled and unskilled labor. This CES measure provides a benchmark of our model taken literally to the data. But the model's key insight about technology affecting relative wages through shifts in relative sector profitability does not hinge on the CES assumption. Thus we prefer our translog measure because the translog is a moregeneral technology, and because it is net of capital deepening unlike the two-factor CES measure which subsumes capital changes into sbtc. We also measured sbtc as simply the observed level change in $S_{k}$ by sector. The ten-country analysis uses this measure because three countries lack sufficient data to construct the translog measure. The correlation among all three measures was high. ${ }^{15}$

\section{Measures of sbtc Based on Computerization}

We also measure skill-biased technological change by levels of computer usage. We have three such measures for the United States. The Berman, et al (1994) measure is the share of computer investment in total investment by four-digit U.S. SIC manufacturing sectors in 1977 , 1982, and 1987. The Autor, et al (1997) measure is the 1984 share of industry employees using a computer for (approximately) three-digit SIC sectors both in manufacturing and services. Finally, the Mishel and Bernstein (1996) measure is computer capital as a share of total capital for two-digit SIC sectors averaged during four time periods: 1963-1973, 19731979, 1979-1989, and 1989-1994. For the United Kingdom we have the share of computer investment in total investment by four-digit U.K. manufacturing sectors in 1986 and 1988.

We think these measures capture the idea that computers' existence (i.e., their usage level) generates sbtc. However, because other forces might also drive sbtc we regard these computerization measures as a complement to our translog measures.

\section{Testing the Sector-Bias Hypothesis With A Consistency Check}

Our first empirical exercise retains the two-factor aspect of the model quite literally by measuring sector skill intensity as skilled employment relative to unskilled employment. For

\footnotetext{
15 For the United States in the 1970s, among the 450 four-digit sectors the correlations among the three measures are as follows: translog with wage-bill 0.89; translog with CES 0.79; and wage-bill with CES 0.98. For the 1980s the analogous correlations are $0.93,0.81$, and 0.96 .
} 
each country we regress measures of sectoral sbtc over some time period--usually the 1970 s and the 1980s--against sector skill intensity at the start of that period. Specifically, if we pool both decades into one equation then for each country we estimate

$$
s b t c k=\alpha+T D 80+\beta_{1}\left(\frac{N_{s}}{N_{u}}\right)_{k} \times T D 70+\beta_{2}\left(\frac{N_{s}}{N_{u}}\right)_{k} \times T D 80+\varepsilon_{k}
$$

where $\mathrm{k}$ indexes sectors, sbtc $_{\mathrm{k}}$ is some sbtc measure, $\left(\mathrm{N}_{\mathrm{s}} / \mathrm{N}_{\mathrm{u}}\right)_{\mathrm{k}}$ measures start-of-period sector skill intensity (either 1970 or 1980), TD70 and TD80 are time dummies for the 1970s and 1980s, and $e_{k}$ is an error term. The coefficients $\beta_{1}$ and $\beta_{2}$ identify the sector bias of sbtc during the 1970s and 1980s, respectively. A positive (negative) coefficient indicates sbtc was concentrated in the skill-intensive (unskill-intensive) sectors.

We then correlate estimates of sbtc's sector bias with contemporaneous wage-inequality changes observed in the data. Our sector-bias hypothesis suggests that rising (falling) skill premia should be associated with more extensive sbtc in the skilled-labor-intensive (unskilledlabor-intensive) sectors. We aim to explain different experiences within countries over decades and within decades across countries. Overall, this part of our empirical analysis is a consistency check of equation (4) against the data. It estimates the sector bias of sbtc and checks whether this sector bias is consistent with sbtc contributing to observed relative-wage changes. Our mandated-wage regressions below do this as well but in addition, under certain conditions they quantify the share of observed changes accounted for by sbtc's sector bias.

Figure 4 uses the U.N. data to set out the histories of wage inequality (measured as the manufacturing-wide average annual nonproduction earnings relative to the average annual production earnings) we aim to explain for a set of ten countries: Austria, Australia, Denmark, Finland, Ireland, Japan, Portugal, Sweden, United Kingdom, and United States. ${ }^{16}$

\footnotetext{
${ }^{16}$ To try to minimize data-quality problems we focus on developed countries. Data problems included no employment breakdown between skill levels and excessively few industries with reported data. We tried to sensibly "clean" the data we decided to use. This included omitting sectors with negative relative wages, relative employment, or relative wages above 8.5. By narrowing this set of countries based on incomplete and/or poor quality data we obtained our ten countries. For Ireland, Japan, and Portugal we use only the 1980s because of 1970s data problems; for the remaining seven countries we use both decades.
} 
Figure 4: Changing Wage Inequality Across Ten Countries.
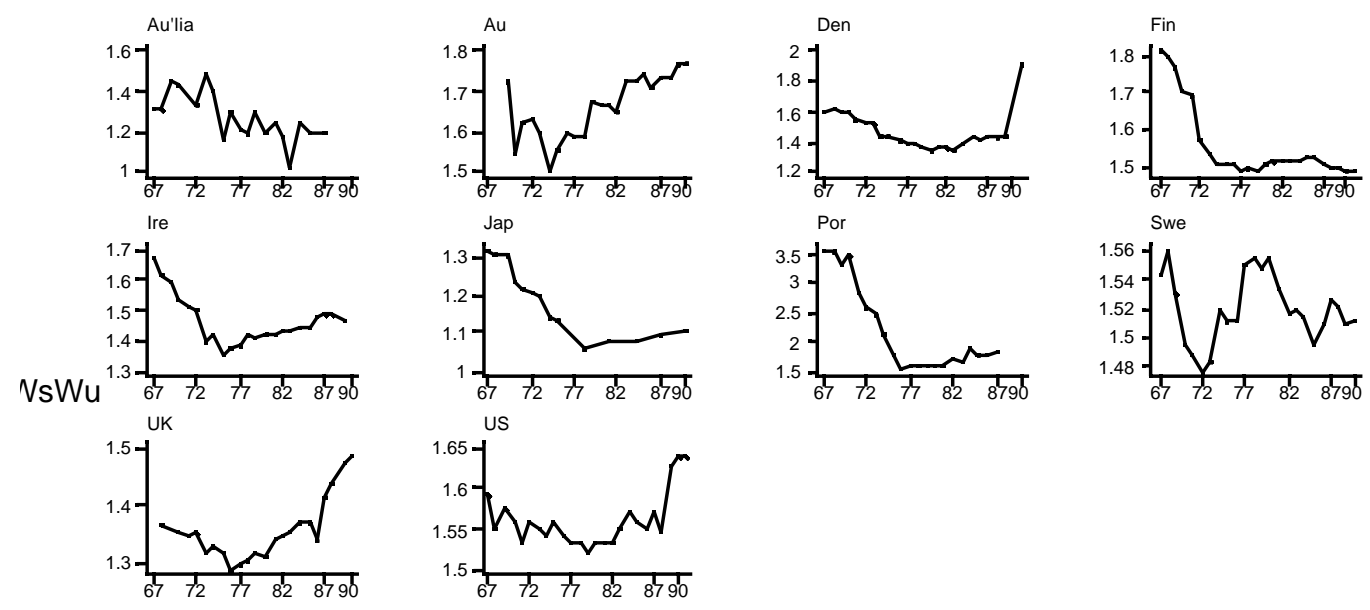

year

As Figure 4 shows, Denmark, the United Kingdom, and the United States all experienced falls in the skill premium over the 1970s and increases in the 1980s. Ireland, Japan, and Portugal all experienced rising skill premia during the 1980s as well (we ignore the 1970s data for these countries). Australia (Aus) and Finland had falling and then flat premia; in Austria (Au) the skill premium rises in both periods. Sweden is an interesting exception: its skill premium rose in the 1970 s and fell in the 1980s. These trends generally match the evidence from other data sources.

\section{4a The United States and United Kingdom}

We begin with the United States and United Kingdom, the two countries for which we have data on more sectors than provided by the U.N. data. Wage inequality in U.S. and U.K. manufacturing fell during the 1970s and then rose sharply during the 1980s (both in the U.N. data and in our more-disaggregated data). According to the sector-bias hypothesis we should find sbtc concentrated in unskill-intensive sectors during the 1970s and then skill-intensive sectors during the 1980s. 
To test this we estimated equation (8) using weighted least squares with industry employment as weights. To visualize the results, Figure 5 plots sbtc (using $\Delta S_{k}$ ) over the 1968-1978 and 1978-1988 against start-of-period (1968 and 1978, respectively) skill intensity for 17 sectors defined congruently across the United States and United Kingdom. The regression lines of best fit clearly support the sector-bias hypothesis.

Figure 5

U.K. and U.S. Sector Bias of SBTC During the 1970s and 1980s

a. $1970 \mathrm{~s}$
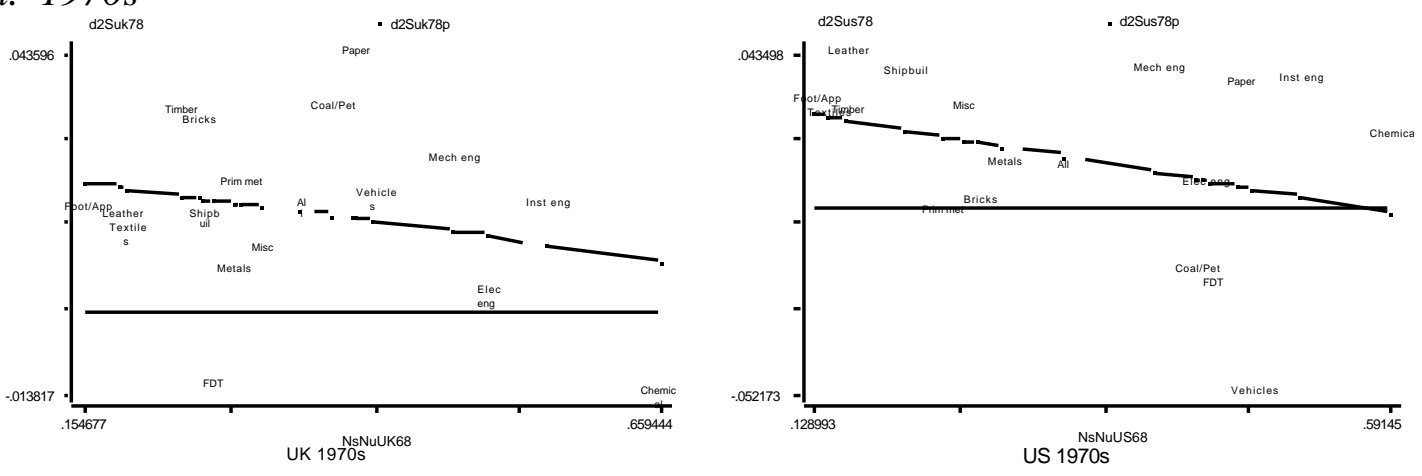

b. $1980 s$
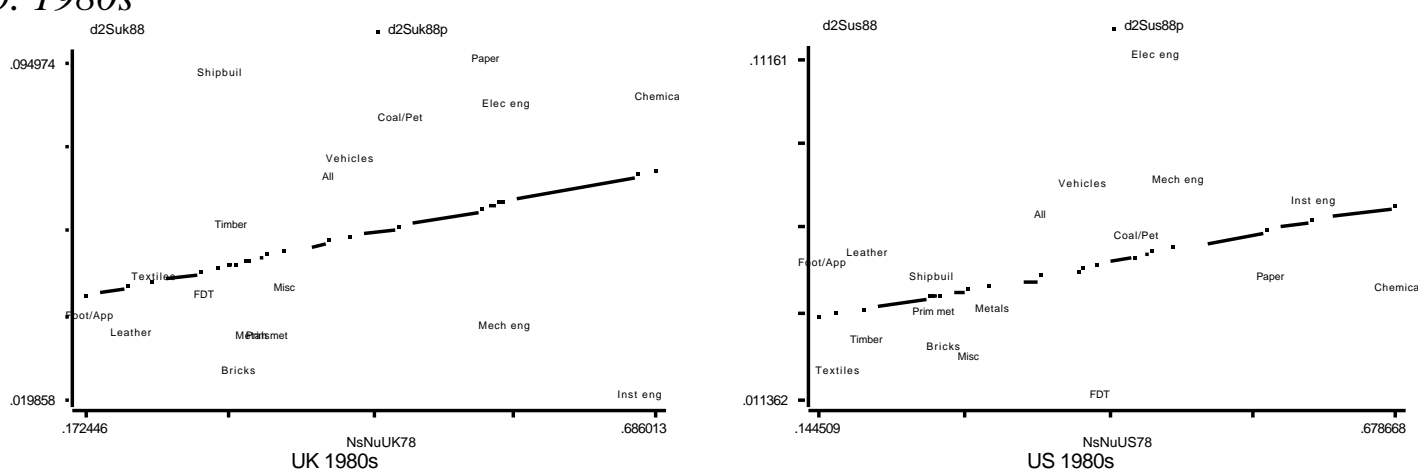

Note: In each diagram the $\mathrm{y}$ axis measures sbtc as $\Delta \mathrm{S}_{\mathrm{k}}$; the $\mathrm{x}$ axis measures start-of-period skill intensity as the skilled/unskilled employment ratio.

Table 1 confirms the message of Figure 5 using more-disaggregated data and the translog sbtc measure to estimate equation (8) for each country. 
Table 1

U.S. and U.K. Sector Bias of SBTC

\begin{tabular}{|c|c|c|}
\hline Country & "U.S. & $\overline{\bar{U} \text { U.K. }}$ \\
\hline$\beta_{1}$ & $\begin{array}{c}-0.03 \\
(-3.76)\end{array}$ & $\begin{array}{c}-0.05 \\
(-2.89)\end{array}$ \\
\hline$\beta_{2}$ & $\begin{array}{c}0.04 \\
(5.64)\end{array}$ & $\begin{array}{c}0.05 \\
(3.19)\end{array}$ \\
\hline$\beta_{1}=\beta_{2}$ ? & (6.54) & $(4.29)$ \\
\hline \# obs & 444 & 125 \\
\hline
\end{tabular}

Note: Each column reports estimation results for equation (9). For brevity the coefficients on the constant and TD80 are not reported. T-statistics or F-statistics based on White's heteroskedasticity-robust standard errors are reported in parentheses. U.S. time periods are 1970 to 1980 and 1980 to 1990 . U.K. time periods are 1968 to 1978 and 1980 to 1989 . Equations estimated by weighted least squares using sector employment as weights.

The negative estimates in row one reveal that in both countries sbtc was significantly concentrated in the unskill-intensive sectors in the 1970s. The significantly positive estimates in row two show that sbtc was concentrated in skill-intensive sectors in the 1980s. The third row reports the F-test statistic confirming that each country had a significantly different sector bias of sbtc across the two decades. Finally, we also modified equation (8) slightly to test whether $\beta_{1}$ or $\beta_{2}$ differed across countries and found no significant difference in the sector bias of sbtc within each decade across countries. This similarity is consistent with the similar wageinequality trends in Figure 4. ${ }^{17}$

Computerization is often identified as a plausible correlate with sbtc. Table 2 reports the results of regressions estimating each of our various computerization measures on its accompanying measure(s) of skill intensity and a constant. All four computerization measures in the table were defined in Section 3.

\footnotetext{
${ }^{17}$ In Table 1 the U.S. regressions omit sectors SIC \# 2026, 2086, 2711, 2721, 2731, and 3761. All these sectors had $\left(\mathrm{N}_{\mathrm{s}} / \mathrm{N}_{\mathrm{u}}\right)$ greater than 1.5, more than three standard deviations from the mean. Our results were robust to including these six sectors. They also were robust to several other checks including weighting all sectors equally, dating the two decades differently (subject to data limitations), and aggregating sectors more broadly (as demonstrated by Figure 5).
} 
Table 2

U.S. and U.K. Sector Bias of SBTC:

Computerization Measures

\begin{tabular}{|c|c|c|c|c|c|c|c|c|c|c|}
\hline Country & & & & U.S. & & U.S. & & & & \\
\hline SBTC & comp & comp & comp & comp & comp & comp & comp & comp & comp & comp \\
\hline Measure & invest & invest & invest & invest & invest & use & stock & stock & stock & stock \\
\hline & 1986 & 1988 & 1977 & 1982 & 1987 & 1984 & '63-'73 & '73-'79 & '79-'89 & '89-'94 \\
\hline$\left(\mathrm{N}_{\mathrm{S}} / \mathrm{N}_{\mathrm{U}}\right)$ & $\begin{array}{c}0.09 \\
(6.29)\end{array}$ & $\begin{array}{c}0.07 \\
(5.05)\end{array}$ & $\begin{array}{c}0.08 \\
(2.89)\end{array}$ & $\begin{array}{c}0.08 \\
(3.25)\end{array}$ & $\begin{array}{c}0.11 \\
(6.62)\end{array}$ & & & & & \\
\hline college grad & & & & & & $\begin{array}{c}0.42 \\
(2.28)\end{array}$ & & & & \\
\hline some & & & & & & 1.45 & & & & \\
\hline college & & & & & & $(4.06)$ & & & & \\
\hline hs grad & & & & & & $\begin{array}{c}-0.35 \\
(-1.83)\end{array}$ & & & & \\
\hline hs dropout & & & & & & $\begin{array}{l}-1.07 \\
(-7.32)\end{array}$ & & & & \\
\hline sci \& eng & & & & & & & $\begin{array}{c}-0.0002 \\
(-0.34)\end{array}$ & $\begin{array}{r}-0.0009 \\
(-0.39)\end{array}$ & $\begin{array}{c}0.03 \\
(2.11)\end{array}$ & $\begin{array}{c}0.06 \\
(2.16)\end{array}$ \\
\hline \# obs & 203 & 200 & 444 & 444 & 444 & 142 & 31 & 31 & 31 & 31 \\
\hline
\end{tabular}

Note: Each column reports estimation results for a different specification of sector computer usage on a constant and sector skill intensity. For brevity the coefficients on the constant are not reported. T-statistics based on White's heteroskedasticity-robust standard errors reported in parentheses. Equations estimated by weighted least squares using sector employment as weights. See text for exact definitions of variables.

Columns 1 and 2 report results for our U.K. computerization measure (available two different years) regressed on sector nonproduction-worker employment relative to productionworker employment. Columns 3 through 5 report the analogous U.S. results for the same computerization measure (from Berman, et al (1994)) available three different years. In both countries in all years, computerization was higher in more skill-intensive sectors. Column 6 reports results for the share of total sector workforce using a computer on the job (from Autor, et al (1997)) regressed on sector educational attainment using four education categories (share of total labor force that reached college graduate; some college; high-school graduate; and highschool dropout). Sectors with a more-educated workforce use computers more heavily. Finally, columns 7 through 10 regress computer capital as a share of total capital (from Mishel and Bernstein (1996)) on the share of sector employment accounted for by scientists and engineers. This relationship was insignificant during the 1960s and 1970s but was significantly positive during the 1980s and early 1990s. Under the assumption that these 
measures of computerization are correlated with sbtc, all these results corroborate the results in Table 1 for the 1980s. In both countries, sbtc was concentrated in the skill-intensive sectors.

To summarize, in both the United States and the United Kingdom wage inequality measured by occupations fell during the 1970s and then rose during the 1980s. The empirical evidence in Figure 5 and Tables 1 and 2 support our hypothesis that the sector bias of sbtc contributed to these wage trends. In both countries sbtc was concentrated in unskill-intensive sectors during the 1970s and then skill-intensive sectors during the 1980s.

\section{$4 b$ Ten Developed Countries}

To test the sector-bias hypothesis further we estimate equation (8) on each of our ten countries. Table 3 reports the results using the $\Delta \mathrm{S}_{\mathrm{k}}$ sbtc measure.

Table 3

The Sector Bias of SBTC In Ten Countries

\begin{tabular}{|c|c|c|c|c|c|}
\hline Country & Aus & $\overline{\mathrm{Au}}$ & $\overline{\text { Den }}$ & $\overline{\text { Fin }}$ & $\overline{\text { Ire }}$ \\
\hline$\overline{\beta_{1}}$ & $\begin{array}{c}-0.09 \\
(-3.03)^{* * *}\end{array}$ & $\begin{array}{c}0.09 \\
(2.24) * *\end{array}$ & $\begin{array}{c}-0.02 \\
(-0.68)\end{array}$ & $\begin{array}{c}0.02 \\
(0.26)\end{array}$ & N.A. \\
\hline$\beta_{2}$ & $\begin{array}{l}-0.01 \\
(-0.43)\end{array}$ & $\begin{array}{c}0.07 \\
(1.72)\end{array}$ & $\begin{array}{c}0.06 \\
(2.17)^{* *}\end{array}$ & $\begin{array}{c}0.11 \\
(2.99)^{* * *}\end{array}$ & $\begin{array}{c}0.17 \\
(2.04) * *\end{array}$ \\
\hline$\beta_{1}=\beta_{2}$ ? & $(3.55) * * *$ & (1.30) & $(3.29)^{* * *}$ & $(3.57) * * *$ & N.A. \\
\hline $\mathrm{R}^{2}$ & 0.37 & 0.56 & 0.38 & 0.65 & 0.47 \\
\hline \# obs & 27,26 & 28,26 & 26,26 & 28,28 & N.A.,24 \\
\hline Data intervals & $1970-80-87$ & $1973-80-90$ & $1970-80-86$ & $1968-78-90$ & $1979-89$ \\
\hline
\end{tabular}

\begin{tabular}{|c|c|c|c|c|c|}
\hline Country & Jap & $\overline{\text { Por }}$ & Swe & $\overline{\mathrm{UK}}$ & $\overline{\mathrm{US}}$ \\
\hline$\beta_{1}$ & N.A. & $\overline{\text { N.A. }}$ & $\begin{array}{c}0.06 \\
(2.34)^{* *}\end{array}$ & $\begin{array}{c}0.03 \\
(1.21)\end{array}$ & $\begin{array}{c}-0.01 \\
(-0.40)\end{array}$ \\
\hline$\beta_{2}$ & $\begin{array}{c}-0.05 \\
(-0.97)\end{array}$ & $\begin{array}{c}0.30 \\
(2.87) * * *\end{array}$ & $\begin{array}{c}-0.02 \\
(-0.71)\end{array}$ & $\begin{array}{c}0.11 \\
(4.20)^{* * *}\end{array}$ & $\begin{array}{c}0.09 \\
(4.39)^{* * *}\end{array}$ \\
\hline$\beta_{1}=\beta_{2}$ ? & N.A. & N.A. & $(5.08) * * *$ & $(4.27)^{* * *}$ & $(7.08)^{* * *}$ \\
\hline $\mathrm{R}^{2}$ & 0.79 & 0.63 & 0.45 & 0.78 & 0.75 \\
\hline \# obs per dec & N.A., 10 & N.A., 27 & 28,28 & 28,28 & 28,28 \\
\hline Data intervals & $1981-90$ & 1980-87 & $1970-80-89$ & $1970-79-89$ & $1969-79-89$ \\
\hline
\end{tabular}

Note: Each column reports estimation results for equation (9). For brevity the coefficients on the constant and TD80 are not reported. T-statistics or F-statistics based on White's heteroskedasticity-robust standard errors are reported in parentheses. $* *$ and $* * *$ denote significance at the $95 \%$ and $99 \%$ levels, respectively. Equations estimated by weighted least squares using sector employment as weights. "N.A." means estimates not available due to data limitations. 
The key message of Table 3 is that the sector bias of sbtc varies over both countries and decades. The 1970s parameter estimates (significance aside) indicate three countries with sbtc concentrated in unskill-intensive sectors and four in skill-intensive sectors. In the 1980s the analogous breakdown is three countries and seven countries. And across the two decades, every country except Austria experienced a statistically significant change in its sector bias of sbtc between the 1970s and the 1980s. ${ }^{18}$

We can test our sector-bias hypothesis by combining the wage-inequality data from Figure 4 with the sbtc-bias estimates from Table 3. Our hypothesis is that country-decades with rising (falling) wage inequality should be country-decades with sbtc biased towards the skill-intensive (unskill-intensive) sectors. We test this in Figure 7 for the 1970s and Figure 8 for the 1980s.

Figure 7

The Sector Bias of SBTC and Changing Wage Inequality in the 1970s

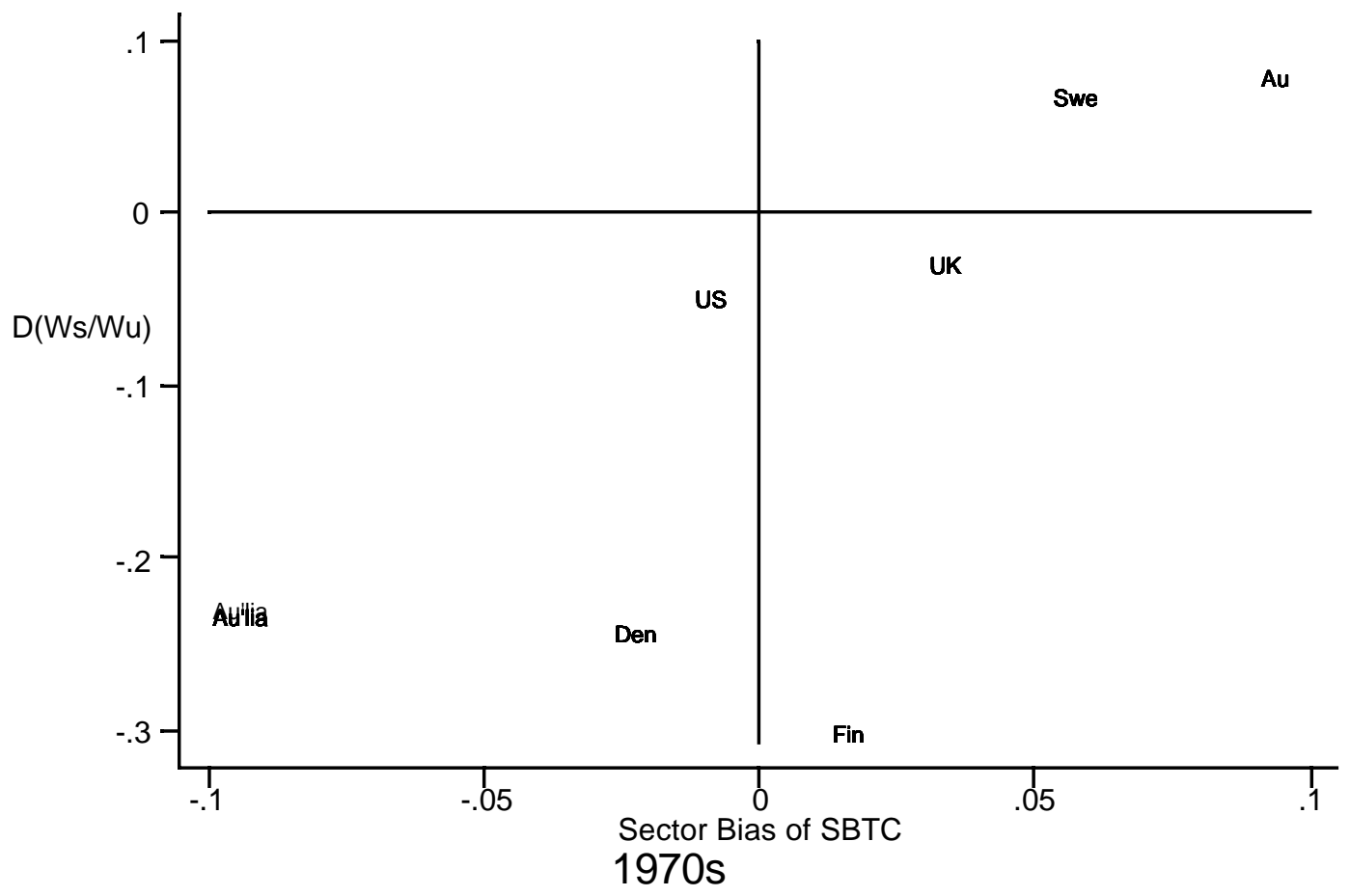

\footnotetext{
18 We report results using the wagebill sbtc measure to maximize country coverage. Because of missing capital-stock data our preferred translog sbtc measure can be constructed for only seven countries. The translog results are qualitatively identical to the wagebill results so we report only the latter. Since changes in wagebill shares can be affected by labour hoarding we try to start and end decades at like points in the business cycle. Table 3 reports years used. To test for cross-country differences, we modified equation (9) by pooling all countries together and estimated all countries together using a full set of country dummy variables for interactions. The parameter estimates for $64 \%$ of the country pairs were significantly different at the 5\% significance level (71\% at the $10 \%$ level).
} 
Figure 8

The Sector Bias of SBTC and Changing Wage Inequality in the 1980s

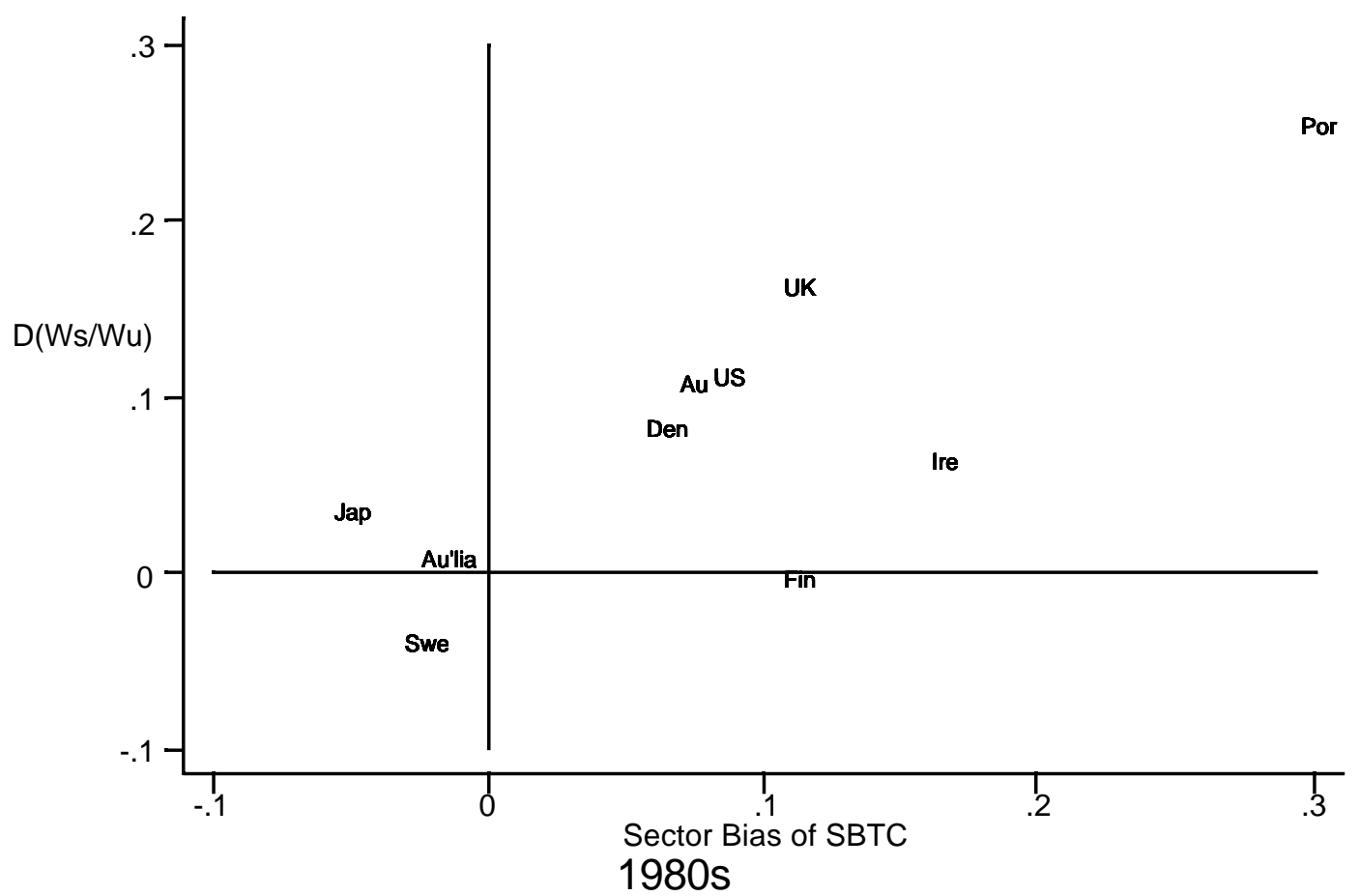

In these figures the horizontal axis plots each country's estimated sector bias of sbtc during that decade (i.e., $\beta_{1}$ or $\beta_{2}$ ) and the vertical axis plots each country's actual wage-inequality change during that decade. The sector-bias hypothesis predicts that all countries should lie either in the upper-right or lower-left quadrant.

Figures 7 and 8 show striking support for the sector-bias hypothesis. Almost all countrydecade observations lie in the lower-left or upper-right quadrants. This indicates that countrydecades with sbtc concentrated in skilled-labor-intensive (unskilled-labor-intensive) sectors tend to have rising (falling) wage inequality. Moreover, not only do most observations lie in the "correct" quadrants, they also generally lie along a positive line. This means that countries with greater (smaller) degrees of sector bias of sbtc tended to experience greater (smaller) rises in wage inequality. This is exactly what our theory predicts.

The pattern does not hold for every country-decade, obviously. This suggests that other forces (such as international trade and labor-market institutions) also affected wage inequality. 
However, the strong overall pattern does suggest that cross-country differences in the sector bias of sbtc is an important explanation for cross-country differences in wage inequality. 19

\section{Testing the Sector-Bias Hypothesis With Mandated-Wage Estimation}

Building on the methodology in Leamer (1996), Baldwin and Cain (1997), and Feenstra and Hanson (1997), in this section we add to Section 4's empirical results by estimating mandated-wage regressions. One important advantage of these regressions is they identify sector skill intensity more accurately by accounting for employment of capital and intermediate inputs. A second important advantage of these regressions is they offer suggestive evidence of the wage changes mandated by the sector bias of sbtc required to maintain zero profits as closely as possible in all sectors. These mandated changes can be compared with actual changes to see what share of actual changes might be accounted for by sbtc's sector bias. For this section we have adequate data for only the United States and the United Kingdom.

\section{Econometric Specification}

We motivate our mandated-wage regressions with a set of zero-profit (price equal average cost) conditions for all sectors in a country:

$$
\boldsymbol{P}=\boldsymbol{A} \times \boldsymbol{W}
$$

where $\mathrm{P}$ is a $(\mathrm{K} \times 1)$ vector of product prices, $\mathrm{W}$ is an $(\mathrm{M} \times 1)$ vector of factor prices, and $\mathrm{A}$ is a (K x M) "technology" matrix whose $\mathrm{a}_{\mathrm{mk}}$ element tells the number of units of factor $\mathrm{m}$ required to produce one unit of product $\mathrm{k}$. It is important to note that in (9), factor prices are not indexed by sector. Recall that our model's assumption of perfect interindustry factor mobility ensures each factor earns one price in all sectors. Thus, for a given $\mathrm{P}$ and $\mathrm{A}$, equation (9) determines the economy-wide factor prices necessary to maintain zero profits in each sector. Note, too, that in contrast to our model the $\mathrm{M}$ factors include primary factors such as

${ }^{19}$ Our results suggest that countries do not share identical production technologies. This finding is supported by Trefler (1993), who explains cross-country differences in wages with cross-country differences in technology. It is also supported by Harrigan (1997), who calculates significant cross-country differences in tfp levels within manufacturing industries among many OECD countries. One possible explanation for these technology differences might be that different countries actually make different product mixes within the sectors for which we have data. Our evidence is consistent with the idea that different countries lie in different "cones of diversification." 
labor and capital and also intermediate inputs such as energy and materials. Because the mandated-wage regressions account for more than nonproduction and production labor they improve upon our empirical evidence in section 4.

Differentiating equation (9) for (sufficiently small) changes yields

$$
\boldsymbol{P}^{*}+\boldsymbol{T F P}^{*}=\theta \times \boldsymbol{W}^{*}
$$

where * denotes percentage changes, $\mathrm{P}^{*}$ is a $(\mathrm{K} \times 1)$ vector of product-price changes, TFP* is a $(\mathrm{K} \times 1)$ vector of total-factor-productivity growth; $\mathrm{W}^{*}$ is an $(\mathrm{M} \times 1)$ vector of domestic factor-price changes, and $\theta$ is a $(\mathrm{K} \times \mathrm{M})$ cost-share matrix whose $\theta_{\mathrm{mk}}$ element tells the share of factor $\mathrm{m}$ in the average cost incurred producing one unit of product $\mathrm{k} \cdot{ }^{20}$ Equation (10) shows the general-equilibrium links among changes in product prices, technology, and factor prices that maintain zero profits in all sectors.

Leamer (1996), Baldwin and Cain (1997), and Feenstra and Hanson (1997) estimate mandated-wage regressions specified as some combination of $\mathrm{P}^{*}$ and/or TFP* regressed on $\theta$. The parameter estimates are interpreted as the $\mathrm{W}^{*}$ mandated by the sector bias of $\mathrm{P}^{*}$ and/or TFP* to maintain zero profits as closely as possible in all sectors. These mandated changes can be compared with actual changes to determine what share of actual changes can be accounted for by $\mathrm{P}^{*}$ and/or TFP*. To estimate the mandated factor-price effects of the sector bias of sbtc, we adjust equation (10) in two important ways.

First, we replace TFP* with sbtc. TFP* encompasses all kinds of technological change-factor biased and factor neutral--but we are focusing on sbtc only. It is important to reemphasize that our measures of the sector bias of pervasive sbtc do not measure the sector bias of cost reductions induced by the sbtc. In contrast, by construction TFP* does measure the sector bias of cost reductions induced by all kinds of technical change. The fact that our sbtc measures are only suggestive of cost reductions means that our mandated-wage regressions with sbtc as the regressand do not have the unambiguous interpretation of

\footnotetext{
${ }^{20}$ Following Leamer (1996), we assume that changes in equation (12) are sufficiently small to ignore any second-order
} effects. 
mandated wage changes. They would have this interpretation only under the assumption that our measures of sbtc indicate the percentage cost reductions induced by sbtc. Nevertheless, we think that our mandated-wage regressions offer suggestive evidence about the wage changes mandated by the sector bias of sbtc. At the very least, the mandated-wage estimatesindicate the sector bias of sbtc more formally than did our analysis in section 4 because, as explained above, this framework measures sector factor intensity more accurately.

Second, we set $\mathrm{P}^{*}=0$. Recall from our model that sbtc's sector bias has a direct effect on wages at unchanged product prices and an indirect effect mediated through changed product prices. Dropping P* allows us to estimate this direct effect. From these direct estimates we will also infer the likely indirect effect of induced product-price changes on factor prices to gauge the total effect of sbtc's sector bias. ${ }^{21}$

With these adjustments, our actual mandated-wage equation is the following:

$$
{ }^{s b t c} k, t-(t-\tau)=\alpha+\beta_{S}\left(\frac{w_{s} N_{s}}{C}\right)_{k, \tau}+\beta_{u}\left(\frac{w_{u} N_{u}}{C}\right)_{k, \tau}+\beta_{K}\left(\frac{r K}{C}\right)_{k, \tau}+\varepsilon_{k}
$$

where $\mathrm{k}$ again indexes sector, $\tau$ is the initial time period, $\mathrm{C}$ is sector total costs as measured in Leamer (1996), $\mathrm{K}$ is the real capital stock, $\mathrm{r}$ is the rate of return earned by capital as measured in Leamer (1996), $\alpha$ is a constant term, $e_{k}$ is the white-noise error term, and the $\beta$ 's are the parameters to be estimated. ${ }^{22}$ Note that like the tfp mandated-wage regressions of Leamer (1996) and Feenstra and Hanson (1997), equation (11) does not contain intermediate inputs as regressors. We exclude these inputs because of our assumption of zero sbtc-induced change in product prices (the prices of intermediate inputs are their output prices).

\footnotetext{
21 Our strategy of assuming no price changes in the estimation but then considering the likely effect of sbtc-induced price changes after the estimation parallels Baldwin and Cain (1997). They use product-price changes as regressands assuming no technology changes and then consider the likely effects of various technology changes.

${ }^{22}$ The factor payments to capital are assumed to be $10 \%$ of book value of plant, equipment, and inventories. Total costs are assumed to be the sum of all labor costs, payments to capital, and intermediate-input purchases. The U.S. and U.K. average cost shares were quite similar. For example, the U.S. 1979 shares and U.K. 1980 shares were 0.09 and 0.10 for nonproduction labor, 0.17 and 0.19 for production labor, and 0.08 and 0.06 for capital. Also, the error term in equation (11) allows the zero-profit conditions not to bind exactly (for whatever unspecified reasons). Because the econometric fit is not perfect, the mandated factor-price changes can be interpreted as the changes consistent with the least change in profits across all sectors.
} 
The parameter estimates of (11) indicate the sector bias of sbtc. A positive $\left(\beta_{\mathrm{s}}-\beta_{\mathrm{u}}\right)$ indicates that sbtc has a sector bias towards the skill-intensive sectors, and a negative $\left(\beta_{\mathrm{s}}-\beta_{\mathrm{u}}\right)$ indicates that sbtc has a sector bias towards the unskill-intensive sectors. These parameter estimates can be interpreted as mandated factor-price changes under the assumption that our measures of sbtc reflect the percentage cost reductions induced by sbtc. In this case the coefficient $\beta_{\mathrm{s}}$ is the percentage change in the economy-wide nonproduction wage mandated by sbtc over that time period. Similarly, $\beta_{\mathrm{u}}$ is the mandated percentage change in the economy-wide production wage. Thus $\left(\beta_{\mathrm{s}}-\beta_{\mathrm{u}}\right)$ is the change in wage inequality mandated by sbtc. The mandated change can be compared to the actual change to determine what share of the actual change can be accounted for by the sector bias of sbtc.

\section{Empirical Results}

Tables 4 and 5 present the estimation results for the 1970s and 1980s, respectively.

Table 4

Mandated-Wage Regressions: 1970s

\begin{tabular}{|c|c|c|c|c|c|c|}
\hline $\begin{array}{c}\text { Equation } \\
\text { Specification }\end{array}$ & $\begin{array}{c}\text { U.S. } \\
\text { weighted } \\
\text { '69 X vars } \\
\text { 1969-1979 }\end{array}$ & $\begin{array}{c}\text { U.S. } \\
\text { unweighted } \\
\text { '69 X vars } \\
1969-1979\end{array}$ & $\begin{array}{c}\text { U.S. } \\
\text { weighted } \\
\text { '71 X vars } \\
1971-1981\end{array}$ & $\begin{array}{c}\text { U.K. } \\
\text { weighted } \\
\text { '68 X vars } \\
1968-1979\end{array}$ & $\begin{array}{c}\text { U.K. } \\
\text { unweighted } \\
\text { '68 X vars } \\
1968-1979\end{array}$ & $\begin{array}{c}\text { U.K. } \\
\text { unweighted } \\
\text { '68 X vars } \\
1968-1976\end{array}$ \\
\hline$\overline{\beta_{\mathrm{s}}}$ & $\begin{array}{c}-0.008 \\
(-0.137)\end{array}$ & $\begin{array}{c}-0.032 \\
(-0.648)\end{array}$ & $\begin{array}{c}-0.007 \\
(-0.120)\end{array}$ & $\begin{array}{c}-0.012 \\
(-0.154)\end{array}$ & $\begin{array}{c}-0.161 \\
(-1.551)\end{array}$ & $\begin{array}{c}0.006 \\
(0.129)\end{array}$ \\
\hline$\beta_{\mathrm{u}}$ & $\begin{array}{c}0.125 \\
(3.752)^{* * *}\end{array}$ & $\begin{array}{c}0.104 \\
(4.700)^{* * *}\end{array}$ & $\begin{array}{c}0.083 \\
(2.092)^{* *}\end{array}$ & $\begin{array}{c}0.241 \\
(5.025)^{* * * *}\end{array}$ & $\begin{array}{c}0.298 \\
(5.910)^{* * *}\end{array}$ & $\begin{array}{c}0.107 \\
(3.737)^{* * *}\end{array}$ \\
\hline$\beta_{\mathrm{k}}$ & $\begin{array}{c}0.050 \\
(0.680)\end{array}$ & $\begin{array}{c}-0.085 \\
(-1.113)\end{array}$ & $\begin{array}{c}0.137 \\
(2.172)^{* *}\end{array}$ & $\begin{array}{c}-0.072 \\
(-1.142)\end{array}$ & $\begin{array}{c}-0.082 \\
(-0.358)\end{array}$ & $\begin{array}{c}-0.545 \\
(-1.916)^{*}\end{array}$ \\
\hline$\left(\beta_{\mathrm{s}}-\beta_{\mathrm{u}}\right)$ & $\begin{array}{l}-0.133 \\
(3.16)^{*}\end{array}$ & $\begin{array}{l}-0.136 \\
(5.16)^{* *}\end{array}$ & $\begin{array}{l}-0.089 \\
(1.27)\end{array}$ & $\begin{array}{c}-0.253 \\
(6.30)^{* *}\end{array}$ & $\begin{array}{c}-0.459 \\
(12.48)^{* * *}\end{array}$ & $\begin{array}{l}-0.101 \\
(2.59)^{*}\end{array}$ \\
\hline Actual $\neq \Delta$ & -0.034 & -0.034 & -0.013 & -0.048 & -0.048 & -0.044 \\
\hline $\mathrm{R}^{2}$ & 0.075 & 0.042 & 0.057 & 0.201 & 0.114 & 0.056 \\
\hline \# obs & 450 & 450 & 450 & 121 & 121 & 121 \\
\hline
\end{tabular}

Note: Each column reports estimation results for a different specification of equation (13). T-statistics based on White's heteroskedasticity-robust standard errors are reported in parentheses. $*, * *$, and $* * *$ denote significance at the $10 \%, 5 \%$, and $1 \%$ levels of significance, respectively. 
Table 5

Mandated-Wage Regressions: 1980s

\begin{tabular}{|c|c|c|c|c|c|c|}
\hline $\begin{array}{c}\text { Equation } \\
\text { Specification }\end{array}$ & $\begin{array}{c}\text { U.S. } \\
\text { weighted } \\
79 \text { X vars } \\
1979-1989\end{array}$ & $\begin{array}{c}\text { U.S. } \\
\text { unweighted } \\
\text { '79 X vars } \\
1979-1989\end{array}$ & $\begin{array}{c}\text { U.S. } \\
\text { weighted } \\
\text { '81 X vars } \\
1981-1991\end{array}$ & $\begin{array}{c}\text { U.K. } \\
\text { weighted } \\
\text { '79 X vars } \\
\text { 1979-1986 }\end{array}$ & $\begin{array}{c}\text { U.K. } \\
\text { unweighted } \\
\text { '79 X vars } \\
1979-1986\end{array}$ & $\begin{array}{c}\text { U.K. } \\
\text { weighted } \\
\text { '79 X vars } \\
1979-1982\end{array}$ \\
\hline$\overline{\beta_{s}}$ & $\begin{array}{c}0.170 \\
(4.008)^{* * *}\end{array}$ & $\begin{array}{c}0.081 \\
(2.044)^{* *}\end{array}$ & $\begin{array}{c}0.120 \\
(2.224)^{* *}\end{array}$ & $\begin{array}{c}0.215 \\
(3.186)\end{array}$ & $\begin{array}{c}0.296 \\
(2.730)^{* *}\end{array}$ & $\begin{array}{c}0.084 \\
(1.82)^{*}\end{array}$ \\
\hline$\beta_{\mathrm{u}}$ & $\begin{array}{c}-0.006 \\
(-0.180)\end{array}$ & $\begin{array}{c}0.024 \\
(0.792)\end{array}$ & $\begin{array}{c}-0.004 \\
(-0.098)\end{array}$ & $\begin{array}{c}-0.098 \\
(-2.073)\end{array}$ & $\begin{array}{c}-0.093 \\
(-1.536)\end{array}$ & $\begin{array}{c}-0.032 \\
(-0.925)\end{array}$ \\
\hline$\beta_{\mathrm{k}}$ & $\begin{array}{c}0.171 \\
(2.527)^{* *}\end{array}$ & $\begin{array}{c}0.097 \\
(1.445)\end{array}$ & $\begin{array}{c}0.028 \\
(0.307)\end{array}$ & $\begin{array}{c}0.012 \\
(0.255)\end{array}$ & $\begin{array}{c}-0.015 \\
(-0.283)\end{array}$ & $\begin{array}{c}0.065 \\
(2.135)^{* *}\end{array}$ \\
\hline$\left(\beta_{\mathrm{s}}-\beta_{\mathrm{u}}\right)$ & $\begin{array}{c}0.176 \\
(7.37)^{* * *}\end{array}$ & $\begin{array}{l}0.057 \\
(1.01)\end{array}$ & $\begin{array}{l}0.124 \\
(2.43)\end{array}$ & $\begin{array}{c}0.313 \\
(11.72)^{* * *}\end{array}$ & $\begin{array}{c}0.389 \\
(7.31)^{* * *}\end{array}$ & $\begin{array}{l}0.116 \\
(3.43)\end{array}$ \\
\hline Actual $\neq \Delta$ & 0.067 & 0.067 & 0.072 & 0.124 & 0.124 & 0.090 \\
\hline $\mathrm{R}^{2}$ & 0.120 & 0.020 & 0.052 & 0.103 & 0.060 & 0.023 \\
\hline \# obs & 449 & 449 & 448 & 125 & 125 & 125 \\
\hline
\end{tabular}

Note: Each column reports estimation results for a different specification of equation (13).

T-statistics based on White's heteroskedasticity-robust standard errors are reported in parentheses.

$*, * *$, and $* * *$ denote significance at the $10 \%, 5 \%$, and $1 \%$ levels of significance, respectively.

In the tables each column reports estimation results for a different specification of equation (11). In each column the first three rows report $\beta_{\mathrm{s}}, \beta_{\mathrm{u}}$, and $\beta_{\mathrm{k}}$ (and t-statistics). Row four reports $\left(\beta_{\mathrm{s}}-\beta_{\mathrm{u}}\right)$ and the F-statistic testing whether this is significantly different from zero. For comparison, row five reports the relevant actual percentage change in inequality (measured as the manufacturing-wide average annual nonproduction earnings relative to the average annual production earnings). Each column reports results using our translog-derived sbtc measure. The column headings indicate the country, whether the regression is weighted or unweighted least squares, the dating of the regressors, and the period over which sbtc is measured.

The key message of Table 4 (Table 5) is that sbtc had a sector bias towards the unskillintensive (skill-intensive) sectors in both the United Kingdom and the United States during the 1970s (1980s). For each country-decade all specifications estimate the same sector bias, significantly so in most cases. The tables also show that our findings are robust to the 
weighting of the regressors and the time interval over which sbtc is measured. ${ }^{23}$ As row 5 indicates, both countries experienced declining (rising) inequality during the 1970s (1980s). Thus, in line with our sector-bias hypothesis the data are consistent with the sector bias of sbtc contributing in both countries to declining inequality during the 1970 s and rising inequality during the 1980s.

Under the assumption that our measures of sbtc reflect the percentage cost reductions induced by sbtc, for both countries in both decades the mandated inequality changes match the direction of, but exceed (in absolute value), actual inequality changes. This suggests that in addition to the direct effect of sbtc at unchanged product prices, other forces were affecting wage inequality. One force might have been sbtc's indirect effect on wages through induced product-price changes. Our model from Section 2 shows that worldwide sbtc concentrated in unskill-intensive sectors can increase wage inequality indirectly by increasing the relative output and thus reducing the relative price of these sectors (see Figure 3). Analogously, worldwide sbtc concentrated in skill-intensive sectors can reduce wage inequality indirectly. The U.S. price evidence is consistent with these indirect effects. For 1970s manufacturing, Leamer (1996) and Baldwin and Cain (1997) estimate relative-price declines for unskillintensive sectors. And Lawrence and Slaughter (1993), Leamer (1996), and Baldwin and Cain (1997) estimate relative-price declines for skill-intensive manufacturing sectors in the 1980s.

Finally, Table 6 reports additional results for the 1980s proxying for sbtc with our data on computer investment as a share of total investment.

\footnotetext{
${ }^{23}$ We tested the robustness of our results several ways including measuring sbtc differently, weighting sectors equally or by sector size, measuring cost shares different years near the starting point, and timing the decades differently. Our results are robust to all these checks. U.K. regression weights are sector employment. U.S. employment weights are sector value of shipments; regressions with employment weights many times yield slightly stronger results, so for robustness we report the "weakest" weighted results. For brevity we do not report parameter estimates for the constant.
} 
Table 6

Mandated-Wage Regressions: United States and United Kingdom, 1980s

\begin{tabular}{|c|c|c|c|c|c|}
\hline $\begin{array}{c}\text { Equation } \\
\text { Specification }\end{array}$ & $\begin{array}{c}(\mathrm{CI} / \mathrm{I})_{1977} \\
\text { weighted } \\
\text { U.S. }\end{array}$ & $\begin{array}{c}(\mathrm{CI} / \mathrm{I})_{1982} \\
\text { weighted } \\
\text { U.S. }\end{array}$ & $\begin{array}{c}(\mathrm{CI} / \mathrm{I})_{1987} \\
\text { weighted } \\
\text { U.S. }\end{array}$ & $\begin{array}{c}(\mathrm{CI} / \mathrm{I})_{1986} \\
\text { weighted } \\
\text { U.K. }\end{array}$ & $\begin{array}{c}(\mathrm{CI} / \mathrm{I})_{1988} \\
\text { weighted } \\
\text { U.K. }\end{array}$ \\
\hline$\overline{\beta_{s}}$ & $\begin{array}{c}0.368 \\
(3.910)^{* * *}\end{array}$ & $\begin{array}{c}0.443 \\
(7.782)^{* * *}\end{array}$ & $\begin{array}{c}0.670 \\
(7.110)^{* * *}\end{array}$ & $\begin{array}{c}0.986 \\
(12.783)^{* * *}\end{array}$ & $\begin{array}{c}0.865 \\
(12.986)^{* * * *}\end{array}$ \\
\hline$\beta_{\mathrm{u}}$ & $\begin{array}{c}-0.043 \\
(-0.840)\end{array}$ & $\begin{array}{c}-0.089 \\
(-1.494)\end{array}$ & $\begin{array}{c}-0.217 \\
(-3.361)^{* * *}\end{array}$ & $\begin{array}{c}0.232 \\
(3.655)^{* * *}\end{array}$ & $\begin{array}{l}-0.072 \\
(-1.236)\end{array}$ \\
\hline$\beta_{\mathrm{k}}$ & $\begin{array}{c}-0.120 \\
(-1.756)^{*}\end{array}$ & $\begin{array}{c}-0.117 \\
(-2.297)^{* *}\end{array}$ & $\begin{array}{c}-0.207 \\
(-2.314)^{* *}\end{array}$ & $\begin{array}{c}-0.616 \\
(-3.140)^{* * *}\end{array}$ & $\begin{array}{c}-0.783 \\
(-4.105) * * *\end{array}$ \\
\hline$\left(\beta_{\mathrm{s}}-\beta_{\mathrm{u}}\right)$ & $\begin{array}{l}0.411 \\
(9.82)\end{array}$ & $\begin{array}{c}0.560 \\
(23.49)\end{array}$ & $\begin{array}{c}0.877 \\
(42.45)\end{array}$ & 0.754 & 0.937 \\
\hline $\mathrm{R}^{2}$ & 0.332 & 0.541 & 0.526 & 0.705 & 0.713 \\
\hline \# obs & 450 & 450 & 450 & 78 & 78 \\
\hline
\end{tabular}

In these specifications, the difference $\left(\beta_{\mathrm{s}}-\beta_{\mathrm{u}}\right)$ cannot be easily interpreted as the mandated change in inequality because our computer-investment regressands cover a single year rather than spanning some time period. Nevertheless, this difference does indicate the sector bias of computer investment. All five specifications indicate a strong bias of computerization towards the skill-intensive sectors. Moreover, the bias has strengthened over time for the United States. We interpret Table 6 as suggestive evidence corroborating Table $5 .^{24}$

\section{Relating Our Empirical Results to the Literature}

Our regressions are the first to estimate wage changes mandated by the sector bias of sbtc. In contrast, Leamer (1996) and Baldwin and Cain (1997) analyze the sector bias of $\mathrm{P}^{*}$ while Leamer (1996) and Feenstra and Hanson (1997) analyze the sector bias of TFP*.

Leamer (1996) finds quite different mandated changes in U.S. wage inequality from the sector bias of tfp. Assuming no effect of tfp on product prices, he estimates mandated rises in wage inequality during the 1970 s and mandated declines in wage inequality during the 1980 s.

\footnotetext{
${ }^{24}$ Importantly, we are assuming some link between computers and sbtc. We do not control for the fact that computers might trigger ubtc and/or factor-neutral tc in addition to (or instead of) sbtc (as we discuss, Feenstra and Hanson (1997) address this issue). Also, because forces other than computerization can cause sbtc we prefer our translog sbtc measure.
} 
These tfp-mandated changes are the opposite direction from actual changes in both decades. The contrast between our sbtc results and Leamer's tfp results highlight that tfp is a combination of factor-biased and factor-neutral tc. The sector biases of ubtc and/or factorneutral tc may have outweighed that of sbtc. This is an issue for future research.

Feenstra and Hanson (1997) decompose tfp into parts attributable to computerization (measured several ways) and outsourcing. They then separately estimate mandated wage changes caused by each of these two forces. Our computerization results for the 1980s qualitatively match theirs: a mandated rise in inequality. ${ }^{25}$

Baldwin and Cain (1997) conclude that the sector bias of sbtc contributed to rising U.S. inequality during the 1970s. However, they do not offer any direct evidence of sbtc's sector bias. Instead they reach this conclusion indirectly (p. 43) by ruling out other causes. Also, they do not consider the sector bias of sbtc during the 1970s.

Berman, et al (1997) find similar sbtc (measured by $\Delta \mathrm{S}_{\mathrm{k}}$ ) within sectors across countries. We are of course interested in sbtc within countries across sectors. If sbtc were exactly the same within each sector across all countries, then there would be no difference across countries in the sector bias of sbtc. However, Berman, et al point out in their discussion of their Table 3 that only 13 of 36 country-pairs in their sample have statistically significantly correlated withinsector sbtc over the 1980s. This suggests to us that there are sufficient differences in the extent of sbtc within sectors across countries to allow for important differences across countries in the sector bias of sbtc. Notably, Berman, et al, find that Sweden is not significantly correlated with any county bar Finland.

Many studies (e.g., Berman, et al (1994) and Autor, et al (1997)) document that most of manufacturing-wide skill upgrading is accounted for by within-sector skill upgrading rather than between-sector shifts towards more skill-intensive sectors. The relatively small betweensector shifts are sometimes interpreted as support for the hypothesis that sbtc explains rising

\footnotetext{
25 It is important to note that the Feenstra and Hanson approach to computers is more structural than ours because it relates computers to tfp and thus factor-biased and factor neutral tc--not just sbtc. We use computers assuming that computers are correlated with sbtc in particular.
} 
inequality. In our framework, by definition sbtc generates within-sector shifts. But with sector bias, sbtc also generates between-sector shifts of factors (in response to shifts in relative profitability across sectors). Thus if sbtc is changing inequality our sector-bias hypothesis predicts both within and between-sector shifts. Without further assumptions our model does not predict the relative importance of within and between-sector shifts.

Finally, notice that the sector bias of sbtc estimated by our U.K. and U.S. mandated-wage regressions matches the sector bias of sbtc estimated for these countries in Section 4. This suggests that even though data limitations prevent estimation of mandated-wage regressions for other countries, our initial analysis correctly identified the sector bias of sbtc for them.

\section{Conclusion}

We have examined whether the sector bias of skill-biased technological change (sbtc) explains changing skill premia. There are two main results. First, using a two-factor, twosector model we demonstrated that in many cases it is the sectorbias of sbtc that determines sbtc's effect on relative factor prices, not its factor bias. Second, we presented empirical evidence strongly supporting this sector-bias hypothesis. For a sample of ten countries we found a strong correlation between changes in skill premia and the sectoral bias of sbtc during the 1970s and 1980s. And for the United States and the United Kingdom, estimates of wage changes "mandated" to maintain zero profits in all sectors in response to the sector bias of sbtc matched the direction of actual wage changes. Thus, the empirical evidence suggests that the sector bias of sbtc helps explain changing skill premia within countries in recent decades.

Our research raises at least two questions for future work. First sbtc measures do not indicate the cost reductions induced by the innovation. This information is needed to better understand wage changes mandated by sbtc. Future work might try to decompose tfp into factor-biased and factor-neutral components. Second, our model--like many standard trade models--predicts that national labor-supply changes do not affect wages (unless the supply shock is big enough to change the country's product mix). Future work might try to identify empirically-relevant modifications to standard models to allow factor supplies to matter more. 


\section{References}

Autor, David H., Lawrence F. Katz, and Alan B. Krueger, "Computing Inequality: Have Computers Changed the Labor Market?", Princeton University Industrial Relations Section Working Paper \#377, March 1997.

Baldwin, Robert E. and Glen G. Cain, "Shifts in U.S. Relative Wages: The Role of Trade, Technology, and Factor Endowments," National Bureau of Economic Research Working Paper \#5934, February 1997.

Berman, Eli, John Bound, and Zvi Griliches, "Changes in the Demand for Skilled Labor within U.S. Manufacturing: Evidence from the Annual Survey of Manufactures," Quarterly Journal of Economics, May 1994, pp. 367-397.

Berman, Eli, John Bound, and Stephen Machin, "Implications of Skill-Biased Technological Change: International Evidence,” NBER Working Paper \#6166, September 1997.

Berndt, Ernst R. and David O. Wood, "The Specification and Measurement of Technical Change in U.S. Manufacturing," in Advances in the Economics of Energy and Resources, Volume 4, JAI Press, 1982, pp. 199-221.

Bhagwati, Jagdish and Vivek Dehejia, "Free Trade and Wages of the Unskilled: Is Marx Striking Again," in Bhagwati, J. and Marvin Kosters (eds) Trade and Wages, Washington, D.C.: American Enterprise Institute, 1994, pp. 36-75.

Binswanger, Hans P., "The Measurement of Technical Change Biases with Many Factors of Production," American Economic Review, December 1974, pp. 964-976.

Blau, Francine, D., and Lawrence Kahn, "International Differences in Male Wage Inequality: Institutions versus Market Forces", Journal of Political Economy, August 1996, pp. 791-837.

Bound, John and George Johnson, "Changes in the Structure of Wages in the 1980s: An Evaluation of Alternative Explanations," American Economic Review, June 1992, pp.371-392.

Davis, Steven J., "Cross-Country Patterns of Changes in Relative Wages", in O. Blanchard and S. Fischer (eds) NBER Macroeconomics Annual, New York, 1992, pp. 239-92.

Davis, Donald R., "Technology, Unemployment and Relative Wages in a Global Economy", National Bureau of Economic Research Working Paper \#5636, June 1996, forthcoming European Economic Review, 1997.

Deardorff, Alan and Dalia Haikura "Trade and Wages: What Are the Questions?", in Jagdish Bhagwati and Marvin Kosters (eds) Trade and Wages: Leveling Wages Down?, Washington, D.C.: American Enterprise Institute, 1994, pp. 36-75.

Feenstra, Robert C. and Gordon H. Hanson, "Productivity Measurement and the Impact of Trade and Technology on Wages: Estimates For the U.S., 1972-1990," National Bureau of Economic Research Working Paper \#6052, June 1997.

Findlay, Ronald and Harry Grubert, "Factor Intensities, Technological Progress, and the Terms of Trade," Oxford Economic Papers, 1959, Volume 11, pp. 111-121.

Fortin, Nicole and Thomas Lemieux, "Institutional Changes and Rising Wage Inequality: Is There a Linkage?", Journal of Economic Perspectives, 11, 2, Spring 1997, pp. 75-96.

Freeman, Richard B., "Are Your Wages Set in Beijing?" Journal of Economic Perspectives, Summer 1995, pp. 15-32. 
Hamermesh, Daniel, Labor Demand, Princeton, NJ: Princeton University Press, 1993.

Harrigan, James, "Estimation of Cross-Country Differences in Industry Productivity", National Bureau of Economic Research Working Paper \#6121, August 1997.

Howell, David, "The Collapse of Low-Skill Male Earnings in the 1980s," New School of Social Research mimeograph, 1995.

Johnson, George, "Changes in Earnings Inequality: The Role of Demand Shifts," Journal of Economic Perspectives, 11, 2, Spring 1997, pp. 41-54.

Katz, Lawrence F. and Kevin M. Murphy, "Changes in Relative Wages, 1963-1987: Supply and Demand Factors," Quarterly Journal of Economics, February 1992, pp. 35-78.

Krauss, Melvyn and Harry G. Johnson, General-Equilibrium Analysis, Chicago: Aldine Publishing Company, 1974.

Krueger, Alan B., "How Computers Have Changed the Wage Structure: Evidence from Microdata, 1984-1989," Quarterly Journal of Economics, 108, 1993, pp. 33-60.

Krugman, Paul R., "Technology, Trade, and Factor Prices," National Bureau of Economic Research Working Paper \#5355, November 1995.

Lawrence, Robert Z. and Matthew J. Slaughter, "International Trade and American Wages in the 1980s: Giant Sucking Sound or Small Hiccup?" in Martin Neil Baily and Clifford Winston (eds) Brookings Papers on Economic Activity: Microeconomics 2, 1993, 161-211.

Leamer, Edward E., "In Search of Stolper-Samuelson Effects On U.S. Wages," National Bureau of Economic Research Working Paper \#5427, January 1996.

Leamer, Edward E., and James Levinsohn, "International Trade Theory: The Evidence," in Handbook on International Economics, Volume 3, 1995.

Mishel, Lawrence and Jared Bernstein, "Technology and the Wage Structure: Has Technology's Impact Accelerated Since the 1970s?", Economic Policy Institute, July 1996.

Oulton, Nick, and M. O'Mahoney, "Productivity and Growth: A Study of British Industry 19541986," NIESR manuscript, London, 1996.

Richardson, J. David, "Income Inequality and Trade: How to Think, What to Conclude," Journal of Economic Perspectives, Summer 1995, pp. 33-55.

Topel, Robert H., "Factor Proportions and Relative Wages: The Supply-Side Determinants of Wage Inequality," Journal of Economic Perspectives, 11, 2, Spring 1997, pp. 55-74.

Trefler, Daniel, "International Factor-Price Differences: Leontief Was Right!" Journal of Political Economy, 1993.

Wood, Adrian, "How Trade Hurt Unskilled Workers," Journal of Economic Perspectives, Summer 1995 , pp. 57-80.

Wood, Adrian, "Did Globalization Cause the Changes in Labor Market Inequalities?" Sussex University mimeograph, March 1998. 